\title{
Statutory Interpretation, Capture, and Tort Law: The Regulatory Compliance Defense
}

\author{
Alan Schwartz, Yale Law School
}

The regulatory compliance defense holds firms liable whose products or product warnings fail to satisfy federal regulatory standards, but does not exculpate firms that comply. Rather, compliance is relevant evidence for a jury to consider in a products liability action. This article argues that the defense should exculpate compliant firms as a matter of law. A Congress that thought about the matter would prefer this judicial construction of an unclear safety statute. To defend this view, the article argues that a legislature can have intentions in a normatively meaningful sense, that claims that a Congress or its agencies are captured by special interests should be nonjusticiable, and that, when a court is in doubt as to what a legislature intended, it should adopt that construction of the relevant statute that would be easiest for the legislature to correct if the court errs. In this case, it is easier for Congress to correct a construction that it intended to exculpate compliant firms than a construction that it did not.

This article considers the relevance for tort liability of a firm's compliance or noncompliance with a federal safety statute or regulation. This issue is worth studying for two reasons. First, there is a great deal of safety regulation, and firms regulated under federal law are often sued in state

This article benefited from comments at the American Law and Economics Association Annual 1999 Meeting; from workshop comments at Fordham, Michigan, Vanderbilt, and Yale Law Schools; and from suggestions by Barry Adler, Ian Ayres, Hanoch Dagan, Alvin Klevorick, Michael E. Levine, Robert Rasmussen, Roberta Romano, Matthew Spitzer, Emerson Tiller, and two referees.

Send correspondence to: Alan Schwartz, Yale Law School, P.O. Box 208215, New Haven, CT 06520-8215; Fax: (203) 432-8260; E-mail: alan.schwartz@yale.edu.

(C)2000 American Law and Economics Association 
courts for producing allegedly defective products. ${ }^{1}$ Thus, the questions asked here have practical significance. Second, the appropriate preemptive reach of national safety laws implicates important issues of statutory interpretation and federalism. Prior studies of what is called the "regulatory compliance defense" slight these broader issues because they take a tort perspective. This article adds a public law perspective and argues from it that the defense should exculpate more firms than it now does. The argument is set in the United States context but is relevant to federal systems generally.

\section{Introduction}

\subsection{The Law}

It is helpful to begin by clarifying what preemption can mean. Preemption has an institutional and a substantive aspect. Regarding the institutional part, preemption can be (1) full: no state court or administrative agency can enter the field; (2) partial for administrative agencies: no state agency can regulate but a state's common law may operate in the area; or (3) partial for courts: a state agency can regulate but courts cannot entertain tort suits. When institutional preemption is partial, so that a state court or agency may enter, the doctrine's substantive aspect becomes relevant. Preemption can be (1) substantively full: a court (or agency) that is not institutionally preempted can hold a firm liable that has violated a relevant federal standard but cannot vary the standard or (2) substantively partial: a court (or agency) cannot permit firms to produce a level of safety that is below the federal standard but can require firms to produce more safety.

Federal safety statutes commonly contain language prohibiting a "state or political subdivision of a state" from varying federal regulations respecting product safety or product safety warnings. A popular addition to this prohibition permits a state to apply to the relevant federal agency for permission to vary the federal standard. Permission is to be granted if

1. An extensive discussion of American safety regulation and the American case law is in Ausness (1996, p. 1210). Ausness also reviews much of the legal literature on the subject. A similar survey is in Campbell (1998). 
the proposed local regulation is more stringent than the federal standard, or is justified by local conditions, and does not unduly burden interstate commerce. A minority of statutes add to these provisions that a state's common law may continue to operate but do not clarify whether this permission relates only to institutional preemption or to substantive preemption as well. Almost no statute contains explicit language respecting the effect that a firm's compliance with a federal regulation should have in a products liability case. ${ }^{2}$

The state courts reject "partial for courts" institutional preemption and adopt partial substantive preemption. Thus, firms can commonly be sued in tort for producing defective products or giving defective warnings when a relevant federal statute or regulation exists. The majority rule in these law suits holds that a firm's failure to comply with a federal statute or regulation is negligence per se, but compliance is not exculpatory as a matter of law. Rather, compliance is relevant evidence for a jury to consider when deciding whether the firm should be held liable in tort. ${ }^{3}$

2. The Appendix briefly describes the preemptive provisions in the leading product safety statutes. The lack of explicit language relating to tort liability has been remarked. A thoughtful commentator observed: "Congress, in enacting these [safety and regulatory] schemes is rarely explicit about its intention to override state tort law," and "there is virtually nothing along the lines of systematic guidance from the federal courts ...." Rabin (1997). Another commentator stated:

When a manufacturer invokes the preemption doctrine as a defense to tort liability, the court must determine whether Congress intended to foreclose tort suits by injured consumers. This task is complicated by the fact that no federal product safety statute explicitly mentions whether such tort claims are preempted. (Ausness, supra note 1, p. 1226)

The courts sometimes hold that tort suits are preempted but often do not. For example, the National Traffic and Motor Vehicle Safety Act generally does not preempt (see, e.g., Myrick v. Frehauf Corp, 1995); the Food, Drug and Cosmetic Act does not preempt (see Viscusi, 1994); the Consumer Product Safety Act does not preempt (see Sherman, 1992); the 1969 cigarette smoking act arguably does not preempt (see Green, 1997); but the Federal Boat Safety Act preempts (see Lewis v. Brunswick Corporation, 1997); and state tort claims that cars are defectively designed if they lack airbags are preempted (see, e.g., Taylor v. General Motors Corp, 1989).

3. This law is authoritatively stated in Restatement of the Law (1997). 


\subsection{The Case for Current Law}

The state courts reject instititutional preemption because safety regulation is within a state's traditional police power. ${ }^{4}$ Regarding substance, courts need a rule of interpretation when a statute is unclear. The current interpretative rule takes safety statutes to enact, or to direct a federal agency to enact, minimum safety standards. ${ }^{5}$ The Restatement of Products Liability explains:

[The law] reflects the traditional view that the standards set by most product safety statutes or regulations generally are only minimum standards. Thus, most product safety statutes or regulations establish a floor of safety below which product sellers fall only at their peril, but they leave open the question of whether a higher standard of product safety should be applied.

This is the general rule, applicable in most cases. (Restatement of the Law, Comment e, 1997)

The substantive aspect of the regulatory compliance defense that holds noncompliant firms liable is not controversial. The federal government has limited enforcement resources and so should welcome private enforcement unless prosecutorial discretion is an essential aspect of the regulatory scheme, or courts lack the competence to decide whether a firm has met the regulatory standard. Neither of these criteria for federal exclusivity seems met in the typical case in which a firm is sued for producing less safety than federal law requires.

It takes more argument to justify rejecting full substantive preemption-i.e., for not exculpating compliant firms-but a good case exists. Initially, there is an argument from silence. If Congress can have intentions in the sense that individual persons do, then the failure of Congress explicitly to preempt state tort suits, when the preemption issue is well

4. Consistent with this view, the Supreme Court held, in Medtronic, Inc. v. Lohr, 1996, that the Medical Device Amendments of 1976, 90 Stat. 539, did not preempt all state tort actions. Justice Stevens began the opinion for the court by remarking, "Throughout our history, the several states have exercised their police power to protect the health and safety of their citizens" (id., p. 475).

5. All safety standards are minimal in the sense that the government permits firms to make products safer or warnings clearer than the standard requires. The current rule of interpretation holds that federal safety standards are minimal in the sense that the state courts cannot permit firms to satisfy a less demanding safety standard than that set by federal law, but can require firms to satisfy a more demanding standard. In this article, the phrase "safety standard" refers both to a regulation of product safety as such and to a regulation of product safety warnings. 
known, implies that Congress wants these suits to proceed. Traditional social choice analysis holds that legislatures cannot have intentions in the way that people do, however. Under majority rule, the same set of legislator preferences sometimes will sustain a variety of legislative outcomes. ${ }^{6}$ Lawyers should conclude from this possibility that legislatures enact laws but do not have "intentions." When a law's words are unclear, a court should choose the interpretation that the relevant social and political norms best imply. ${ }^{7}$

The norms relevant to safety regulation arguably support the interpretative rule that an unclear federal statute should be read to enact minimum safety standards. One such norm is federalism. This norm is advanced by an interpretation that the national interest is satisfied when firms must supply consumers with a reasonable amount of safety, and the local interest is satisfied when the states are free to adjust safety levels upward to reflect local conditions. A second norm is efficiency. A regulator cannot fully foresee the circumstances in which safety standards will be tested. Products liability suits give the state courts current and particular knowledge, which they can use to make optimal adjustments to federal regulations. A third norm is institutional integrity. Congress and the federal agencies can be captured by industry interests, who will then cause federal regulations

\section{A classic statement is}

... so long as a society preserves democratic institutions, its members can expect that some of their social choices will be unordered or inconsistent. And when this is true, no meaningful choice can be made. If [alternative] $y$ is chosen-given the mechanism of choice and the profile of individual valuations-then to say that [alternative] $x$ is best or right is probably false. But it would also be equally false to say that $y$ is best or right or most desired. And in that sense, the choice lacks meaning. (Riker, 1982)

A less formal statement holds:

The theory of majority cycling has interesting implications for statutory interpretation. The most striking is that even text-based interpretation is hard to link up with majority preferences because there may be several equally plausible majority based preferences in the legislature...the legitimacy of the statute is derived less from majoritarianism (this policy is what most legislators want) than from formalism (this text was agreed to by both chambers of Congress and signed by the president). (Eskridge, 1994, p. 37)

For an application of this view to tort law, see Chapman and Trebilcock (1992).

7. This view is argued in Eskridge (1989). Cass Sunstein makes a similar claim: "Gaps should not be filled in and ambiguities resolved by references to values that counter those of the enacting Congress in particular and the modern regulatory state in general" (Sunstein, 1990, p. 142). See also Dworkin (1986). A concise summary of modern theories of statutory interpretation is in Farber and Frickey (1991, pp. 88-115). 
to require too little safety. State tort law thus can protect the national political process by raising the amount of safety firms must produce to the appropriate level. ${ }^{8}$

\subsection{The Better Interpretative Rule}

This article agrees that state courts should not be institutionally preempted but argues for a new interpretative rule that would require these courts to adopt full substantive preemption: courts applying the proposed rule would take Congress in the usual case to enact "national" rather than minimum safety standards. ${ }^{9}$ A national standard binds the states and so will exculpate firms that comply with it. The proposed rule of interpretation rejects the current interpretative premise that Congress cannot have meaningful intentions respecting safety regulation. Rather, this article con-

8. It is common to justify current law partly on the ground that Congress and its regulators are captured by special interests. The explanatory note to $\S 4$ of the Restatement of Products Liability recites: "In arguing that compliance with agency prescribed warnings should not preclude liability in tort, some commentators have noted that rule making by agencies is often distorted by budgetary limitations, lobbying by special interests, and political pressures [citation]" (Id. at 149). The American Law Institute Reporters' Study, Enterprise Responsibility for Personal Injury, also argued for a regulatory compliance defense that is close to the current one partly on the ground that "the [typical] agency will be 'captured' by backdoor industry influence and adopt inadequate regulations” (American Law Institute's Reporters' Study, 1991). Typical statements in the law reviews hold that "the process of enacting regulations is profoundly sensitive to special-interest pressures and politics, and it is hard to believe that safety regulations represent rational decisions about safety, rather than money politics ... there will be cases when the result is a regulatory regime that is far too lenient on business defendants" (Luban, 1998); and "it is not desirable to have biased agencies who are accountable to all sorts of political organizations mandate what the regulatory standards should be" (Warren, 1997).

9. In this article, when Congress permits a state court to require firms to produce more safety than a federal regulation requires, the regulatory standard is referred to as a minimum. When Congress wants the safety level in a regulation to bind the state courts, the standard is referred to as "national." National standards are not necessarily optimal in the economic efficiency sense; they are only optimal from Congress's viewpoint. An "optimal" national standard thus could sacrifice efficiency to equity. 
tends that Congress has such intentions, which are held on two levels. A Congress that thought about the matter would have a first level preference for courts to apply national rather than minimum safety standards. This preference rests on three grounds. First, a single agency can coordinate regulation to avoid increasing safety in one product dimension at the risk of reducing it in another. Second, firms that sell nationally and must comply with one set of regulatory standards can exploit economies of scale in producing safety. Third, to identify optimal safety standards is a technical task, at which administrative agencies are more expert than courts. As a consequence, when a state does have local knowledge relevant to safety, an efficiency seeking Congress likely would permit state administrative agencies, but not state courts, to enter the field. ${ }^{10}$

Congress also has a second level intention over the interpretative strategies that state courts should pursue. ${ }^{11}$ A legislature should prefer courts to choose the construction of an unclear statute that is easiest for the legislature to correct if the court errs. Applying this strategy here, when a federal safety statute is unclear a state court could make either of two interpretative errors: (1) the court could find that the statute required minimum safety standards when the statute required national standards, or (2) the court could find that the statute required national safety standards when it required only minima. For reasons to be developed in detail below, mistake (2) is easier for Congress to correct than mistake (1). In summary here, a federal agency or a state court has autonomy if it can choose a policy that no other policy in the feasible set "majority defeats." A Congress that intended to enact a minimum safety standard knows that state courts will apply a higher standard on average. Hence, there likely will be a majority for raising the minimum if state courts mistakenly find that Congress intended to enact a national standard. On the other hand, if Congress did want an agency to choose a national standard and the state courts raise that standard on average, there may be no majority (it will

10. This inference helps to explain why federal safety statutes sometimes permit state administrative agencies to request permission from the relevant federal agency to vary federal standards. Courts cannot make such requests.

11. Cass Sunstein refers to and justifies a set of interpretative norms that he calls "interpretative instructions." These norms hold that "courts interpret statutes by concluding that Congress would prefer a particular interpretative strategy" (Sunstein, supra note 7 , p. 153). 
be shown) that would vote to reverse. Therefore, if a state court is unsure whether Congress intended full or partial substantive preemption, it should take Congress to have enacted full preemption (i.e., to have enacted a national safety standard).

\subsection{Responses to the Case for Current Law}

The claim that legislatures cannot have intentions is overdrawn. Recent work in social choice theory shows that legislatures commonly choose statutes from the set of majority preferred policies. ${ }^{12}$ Although a legislature can have intentions in this sense, the argument from silence that Congress prefers never to preempt the state courts substantively is unpersuasive. As indicated above, federal safety statutes explicitly prevent states or political subdivisions thereof from varying federal safety standards (unless in some cases a federal agency approves a variance). A legislative intention to prevent state legislatures, city and county governments, and state and local administrative agencies from raising federal safety standards, but to permit state courts to raise these standards, would be intelligible if either of two conditions were satisfied: (1) local courts are better safety regulators than the state institutions that are explicitly preempted or (2) local courts and juries better reflect the values of a state respecting safety than the explicitly preempted state institutions. It is argued below, however, that state courts are relatively poor regulators and are less representative than state legislatures or local governments. Federal statutes omit explicitly to oust courts probably because Congress rejects institutional preemption. Congress, that is, could sensibly prefer the state

12. Dworkin, supra note 7 , argues that courts should not be bound by legislative intentions, not because these do not exist, but because the courts' obligation to make the law globally coherent should induce a court to prefer the interpretation that renders a statute consistent with the body of statutory law generally to an interpretation that may better reflect the will of a particular enacting legislature. The requirement of global coherence may be justifiable when a common law court is reading common law precedents, for the court is then the keeper of its own law. It is more difficult to see how requiring the Congress to be consistent across election cycles is consistent with a commitment to democracy. Raz makes a similar point, arguing that "if the set of principles one is considering represents the dictates of authority, they may fail to cohere and yet be valid because the authority is a legitimate one with power to bind its subjects" and that "The reality of politics leaves the law untidy.... In countries with decent constitutions, the untidiness of politics is morally sanctioned. It is sanctioned by the morality of authoritative institutions" (Raz, 1994). 
courts to entertain damage suits for the violation of Federal standards to prevent the law from being underenforced and to ensure compensation to the victims of these violations. In brief, an intelligible public purpose seldom would be served by substantively preempting every local legal institution except courts, but intelligible public purposes commonly are served by not preempting local courts institutionally. Therefore, the argument from silence turns out to support the case for substantive but not for institutional judicial preemption. ${ }^{13}$

The three relevant norms of safety regulation, summarized above, also do not support the current tort law rule, that the state courts never are fully prempted. The first such norm was federalism, but the federalism justification for current law is weak. In the contexts at issue here, Congress has explicitly preempted "states and political subdivisions of states" from varying federal safety standards. Thus, a federalism defense of current law apparently must claim that safety regulation at the local level is desirable only if the state courts supply it. This is a weak claim because state courts are poor regulators relative to other local legal institutions.

The second norm was efficiency, but the claim that state tort law is a useful supplement to efficiency based federal regulation will commonly fall on institutional grounds. The issue here is not whether state tort law should operate at all but whether state courts can improve the work of an efficiency seeking federal regulator. This is unlikely for two reasons. First, state courts and juries have fewer resources and less expertise than federal agencies have. Second, state juries are not asked whether a statute or regulation is efficient; they are asked whether a product is less safe than the "ordinary consumer" would expect or poses a "risk" that exceeds its "benefits." 14 These instructions do not state an efficiency test, and so a jury acting under them is unlikely to find the efficient safety level.

13. There are two other versions of the argument from silence. First, the argument summarized in text above may have applied to the first litigated safety statute that did not explicitly preempt state courts, but Congress continues not to resolve the issue. Congress's failure over time to correct what seems a misreading of its intent suggests that current doctrine is not a misreading. Second, courts should hold that Congress does not intend to preempt in order to force Congress to be explicit about what it does want. Neither of these versions of the argument from silence are persuasive (see Part 3.3 infra.)

14. For example, the standard California Jury Instruction regarding the claim that a product is defectively designed provides that "A product is defective in design: (1) If it fails to perform as safely as an ordinary consumer would expect when used in an 
The third norm was institutional integrity, but the argument that special interest interventions in the political process justify partial substantive preemption cannot be taken seriously in the context of state court applications of federal statutes and regulations. While the national political process often is imperfect, the concept of capture, it will be argued below, is nonjusticiable except when there is fraud, concealment, or actual corruption. To give the flavor of a complex argument, a claim that a statutory or administrative rule was the product of capture is a claim that "political market failure" occurred: a normatively undesirable statute was passed in consequence of the existence of invidious political factors. The question when a statute was the product of such factors or represented a normatively permissible compromise in a democracy, however, seldom is answerable with today's analytic tools. A state court's effective choice therefore is either to presume that all safety statutes (or regulations) are the product of bad political processes or that none are. The current rule of interpretation makes the former choice: the state courts today assume that the national political process always is biased downward as regards safety so that they may raise regulatory safety levels unless explicitly prohibited. An assumption that national safety statutes usually lack legitimacy seems precluded by the supremacy clause. Hence, the state courts should presume that the national government has acted appropriately. ${ }^{15}$

Part 2 below first defends the concept of a legislative intention. Part 3 next argues for an interpretative rule that takes Congress, in the absence of good evidence, to intend to enact national safety standards. Part 4 then justifies putting the intellectual burden of proof on those who oppose preemption by developing and illustrating the application here of the interpretative rule that courts should choose the linguistically plausible construction of a statute that is easiest for the legislature to correct if it

intended or foreseeable manner; or (2) If there is a risk of danger in the design which outweighs the benefits of that design." The instruction is cited in Cupp (1997).

15. In analyzing a similar problem, Jerry Mashaw states, "In some sense, all legislation is special interest legislation." As a consequence, a court exercising rationality review should strike a statute only when (1) the statute exhibits "the lack of a coherent and plausible public purpose" and (2) "the underlying structure of competition in the political market place suggests that self-correction is unlikely." That is, "there must also be probable legislative failure" (Mashaw 1997, pp. 66, 75-76). Mashaw does not flesh out the concept of legislative failure. This article argues that this would have been hard to do under the current understanding. 
intended a different result. Part 5 analyzes the capture concept. Part 6 is a conclusion. There have been a large number of articles in the scholarly and popular press that assess the justice and economic efficiency of Products Liability Law. This article takes a different tack, to suggest that an important part of this law may lack political legitimacy.

Before developing the case for this conclusion, a final comment about the argument may be helpful. This article argues for a shift in the burden of proof regarding the effect of federal safety standards. The current state law rule is strong: Section 4 of the Restatement recites that "a product's compliance with an applicable safety statute or administrative regulation is properly considered [by the jury] ... but such compliance does not preclude as a matter of law a finding of product defect." The state courts thus do not ask, in particular cases, whether a court has a comparative advantage over an administrative agency in creating the type of rule at issue; rather, cases routinely are sent to juries to decide whether products are defective. The interpretative rule argued for here would require a state court to find compliance with a federal safety statute or regulation to be exculpatory as a matter of law, unless the court identified reasons of comparative institutional competence or federalism that could plausibly have led a public regarding Congress to delegate to tort law a portion of the regulatory task. The burden of proof should shift in favor of preemption in this way, it is argued here, because these reasons are absent in the common case. The proposed interpretative rule sometimes would permit the state courts to function substantively though the federal government had previously acted, but full preemption would be the usual result.

\section{The Condorcet Problem, the Core and Legislative Intent}

Part 2 makes a general argument, using safety regulation as an example, that a legislature can have intentions in a normatively meaningful sense. The argument is meant to justify claims that take the form, "A Congress that thought about the matter would prefer...." Whether these claims are persuasive turns on their own merits.

American legislatures commonly use majority rule to make social choices. This method requires a polity with $n$ voters to choose policy $x$ over policy $y$ if a simple majority $(n / 2+1)$ prefers $x$. Majority rule always picks a winner when there are two choices but may not be decisive 
when the option set expands. Majority rule proponents argue that, for large choice sets, the policy that beats every other policy in a pair wise vote is the majority's preference. This view has intuitive appeal, and the policy that passes the test is called the Condorcet winner. ${ }^{16}$ A Condorcet winner will not always exist for complex social decisions, however.

To explore the relevance of this possibility, assume that the preferences of each voter in a legislature are complete (the voter has preferences over all of the feasible alternatives), consistent, continuous, and convex. ${ }^{17}$ These assumptions imply that the set of preference maximizing alternatives for each voter is not empty and that the voter's utility declines as outcomes move in "policy space" away from her ideal policy in any direction. An example illustrates how there may not be a Condorcet winner for a complex social decision. In the example, a three-person legislature is to supply an administrative agency with criteria for regulating automobiles. The choice is three-dimensional: the agency is to consider safety, handling ability, and fuel economy. One policy choice, labeled $x$, is to instruct the agency to rank product safety first. A second policy, denoted $y$, would instruct the agency to rank good handling qualities highest. The third policy, $z$, ranks fuel economy first. That legislator 1 prefers policy $x$ to policy $y$ is written $x P_{1} y$. Then assume this legislative "preference profile":

$$
\begin{aligned}
& x P_{1} y P_{1} z \\
& y P_{2} z P_{2} x \\
& z P_{3} x P_{3} y
\end{aligned}
$$

16. See Mueller (1989, p. 114). "If one finds the properties of majority rule most attractive, then failure to select the Condorcet winner when one exists may be regarded as a serious deficiency of a procedure."

17. An individual's preferences are continuous if when the individual prefers alternative $x$ to alternative $y$, there exists an alternative $w$ sufficiently close to $x$ and an alternative $z$ sufficiently close to $y$ such that the individual also prefers $w$ to $z$. The individual's preferences are (strictly) convex if when the individual prefers $x$ to $y$, for any policy alternative $z$ lying on the straight line between $x$ and $y$, the individual also prefers $z$ to $y$ (see Varian, 1992). As an example of convexity, if policy $x$ is spending a lot on education and policy $y$ is spending a little, a person's preferences are strictly convex if when the person prefers spending a lot to a little, the person also prefers spending a moderate amount to a little. The argument in text assumes that a maximum exists in the legislative voting game, which implies the further assumption that the relevant choice sets are compact. 
There is no Condorcet winner in a three-person legislature with this preference profile. Policy $x$ defeats $y$ because legislators 1 and 3 prefer $x$ to $y$; policy $y$ defeats $z$ because legislators 1 and 2 prefer $y$ to $z$; but policy $z$ defeats $x$ because legislators 2 and 3 prefer $z$ to $x$. When there is no Condorcet winner, the result of any one vote cannot represent the legislature's will: for any technologically feasible policy there exists another feasible policy that defeats it in a pairwise vote according to that same legislative will.

This type of result is thought to pose serious difficulties for the project of finding legislative intent. To begin to see why this view is overdrawn, define the set of best (maximal) policy choices given a particular preference profile and a voting aggregation rule (such as majority rule) as the "core" of the aggregation rule under the preference profile. A "core policy" cannot majority defeat other core policies but will majority defeat every noncore policy. The example just set out illustrates an empty core: under the assumed preference profile, no policy could majority defeat all of the other policies in pairwise votes.

The Condorcet problem is a function of the complexity of the decision-the number of dimensions-relative to the number of voters. If the choice is two-dimensional or every voter has the same preferences, then the problem vanishes. As a consequence, the Condorcet problem disaggregates into two questions: (1) Given the choice task, are there legislative preference profiles that will exhibit the Condorcet problem? That is, is it possible for there to be no core? (2) If the lack of a core is a possible outcome of majority rule, what is the chance that the outcome of a particular vote was not a Condorcet winner?

Recent work in social choice theory shows that while the Condorcet problem almost always can exist, typical legislative preference profiles will have a Condorcet winner. Respecting this "possibility result," if a policy choice requires considering $d$ dimensions and there are $n$ voters, then when $d \geq \frac{3(n-3)}{2}$, almost all preference profiles will exhibit the problem. ${ }^{18}$ In the example above, in which $d$ and $n$ both equaled 3 , this inequality is satisfied, so almost every possible preference profile can lack a Condorcet winner.

18. See Austen-Smith and Banks (1997) for a review. 
Turning from possibilities to probabilities, the smaller is the choice set (the fewer the number of dimensions in policy space) relative to the number of voters, the more likely is a preference profile to have a Condorcet winner. Calculating the probability of a Condorcet winner for possible preference profiles is computionally difficult, but recent work suggests that winners commonly exist. There are two studies. One found that when all voter preferences are equally likely (the "impartial culture" assumption), the probability of a Condorcet winner when there are three choice dimensions and three voters is .9444 (Gehrlein, 1998). The second study, using a different methodology with similar assumptions, obtained the identical result (Van Deerman, 1999). ${ }^{19}$ In the usual legislature, there are many more voters than there are dimensions to the typical policy choice. These studies thus strongly suggest that the typical statute is a Condorcet winner. Moreover, if there is no Condorcet winner for a particular preference profile but the number of voters is large relative to the dimensionality of the policy space, majority rule commonly generates social choices that lie within the "uncovered set." Letting $M$ indicate that a policy majority defeats another technically feasible policy, the uncovered set is the set of points $x$ within the policy space $S$ such that for any other alternative $y$ in $S$ either $x M y$ or there exists a $z$ in $S$ such that $x M z M y$ (Mueller, 1989, pp. 185-89; Miller, 1997). Because points in the uncovered set majority defeat points outside, the points in the set are equivalent to Condorcet winners (Ordeshook, 1986). ${ }^{20}$ As a theoretical matter, then, the likelihood

19. The probability figure in text was calculated for linear preference orderings, which require a voter to have strict preferences over all the alternatives in the choice set. A weak preference ordering also is linear but permits the voter to be indifferent as between some of the choices. If voter preferences can be weak orderings, the probability that a Condorcet winner exists for the three-voter, three-dimension case rises to above $99 \%$. This is because adding indifference increases the possible number of voting outcomes but does not increase the number of preference profiles without a Condorcet winner. As regards the intuition for the probabilities above, the preference profile in text had no Condorcet winner, but there is such a winner-it is $x$-for this preference profile: $x P_{1} y P_{1} Z ; x P_{2} z P_{2} y ; z P_{3} x P_{3} y$. It can be shown that there are 216 possible linear preference orderings in the three-voter, three-dimensional case and 12 lack a Condorcet winner. Hence, the probability that there is such a winner is

$$
\frac{204}{216}=.9444 \text {. }
$$

20. Sophisticated voters, such as legislators, will not be led by agenda manipulation to choose points outside the uncovered set (see Shepsle and Weingast, 1984). 
that a particular legislative outcome is in the core-that it reflects the legislative will-is sufficiently high to make plausible the claim that the outcome reflects the legislature's intention.

There remain two further theoretical remarks and a practical remark. As to theory, it can be shown formally that core points are Nash equilibria. To understand this informally, realize that if the legislative status quo did not reflect a core policy, the legislature could vote to overturn the status quo in favor of a new policy, for there would be another feasible policy that would beat the status quo in a majority vote. If the legislature once chose a core policy, however, then this choice would be stable. Continuing with theory, the core may contain more than one policy choice. The size of the core is a function of decisional complexity, the number of voters, and voter heterogeneity. If the core has more than one element, structural considerations commonly determine the policy the legislature will choose. For example, a legislative committee with gatekeeping power (the power not to report proposals) can permit the whole body to vote on some core policies but not others. ${ }^{21}$

As for practice, the modern scholarly tendency is to generalize from an example in which the core is absent given a selected three-voter preference profile over a three-dimensional policy space to the conclusion that legislative outcomes seldom correctly aggregate the preferences of individual legislators. As just shown, the generalization is incorrect. The choice in the auto safety example that began this part had three dimensions and the Congress has several hundred voters. As a consequence, an actual statute that sets criteria for regulating automobiles would be a Condorcet winner with a high probability; that is, the statute would reflect Congress's intentions regarding car safety, in the nontrivial sense that Congressional procedures picked the statute from the set of majority preferred statutes.

21. It may be thought that the power of legislative committees to keep proposals from coming to a vote implies that some statutes embody stable noncore points. This view is plausible but unlikely because there are gains from trade. Since core points are majority preferred, there will be a deal entailing a committee's release of a core proposal (when it would overturn a noncore proposal) that would make all legislators better off. 
The question taken up next is what intention Congress probably has regarding judicial preemption when a safety statute is silent on the issue.

\section{The Appropriate Interpretative Rule}

Part 3 argues that courts should interpret unclear safety statutes to require full substantive preemption because this is the probable legislative intent. The search for intent, it should be said at the outset, should be conducted subject to this constraint: courts should presume that the legislature was pursuing a public purpose. ${ }^{22}$ To see how this constraint operates in the analysis here, Congress may have explicitly preempted all local legal institutions except courts in order to shift wealth to the trial lawyers, but shifting wealth to the trial lawyers is not a public purpose. Congress, however, may be pursuing a safety goal and believe that the state courts can pursue this goal effectively while other state institutions cannot. An argument that a Congress interested in pursuing safety could not plausibly hold such a belief thus counts in this article as an argument in favor of full substantive preemption.

\subsection{The Substantive Argument for National Standards}

Three considerations support the claim that Congress prefers national standards as a general matter. First, when a safety statute does not mention state courts, the question whether Congress meant to preempt these courts substantively turns on what Congress was attempting to achieve. A Congress that wants to permit the states to experiment with forms of safety regulation cannot also want to preempt state institutions from experimenting. Safety statutes commonly preempt almost every state institution, however, which suggests that Congress has rejected significant local experimentation. Second, the existence of a federal statute and a federal regulatory agency imply that Congress has a preference for regulations that have national scope. Regarding the third consideration, federal

22. The justifications for this interpretative constraint are thoughtfully set out in Macey (1986). This article also assumes: (1) a statute or regulation exists that was meant to regulate the product feature that has been challenged in a state law suit; (2) there has been no major, relevant technological change since the statute or regulation was enacted; and (3) regulated firms did not withhold material information from Congress or an agency. When one or more of these assumptions fail, the state courts should be free to create their own regulatory standards. 
statutes state that their goal is to increase safety, but the pursuit of safety simpliciter is not an intelligible goal. For example, a regulation could reduce accidents involving knives by ordering knives to be dulled, but the resultant product would not be a knife. As a consequence, this article takes Congress to want its agencies to produce regulations that make optimal tradeoffs between safety and product utility, but also to attach weight to the federalism norm.

An effective pursuit of optimal product safety often will require national regulation. Uniformity reduces costs because there commonly are economies of scale to production. As a consequence, when firms are required to produce different versions of a product to comply with different state safety standards, each item will be more expensive than it would otherwise have been, and some items may not be produced at all. A single standard thus will often make the best tradeoff between safety and the other benefits that consumers could derive from a product. In addition, increasing the safety of a particular product attribute could make the product less safe as a whole unless other attributes also are modified. This argues for a coordinated form of regulation that the different states could not supply.

There are four responses to the claim that a Congress pursuing optimal safety would enact national safety standards. ${ }^{23}$ Each response attempts to show that efficiency is best achieved with a federal minimum standard that state courts are free to raise. The first response holds that local knowledge can be helpful when devising optimal safety regulations. California regulators may know more about surfboards and Minnesota regulators may know more about snowmobiles than regulators in Washington, DC, do. These products seem exceptional, however. Local knowledge would be unlikely to improve safety standards for swing sets, toasters, lawn mowers, bicycles and other typical consumer products. Also, answers to the question what instructions will best avoid accidents seldom will turn on the state in which the product is used. Swing sets and toasters are forseeably misused in much the same ways everywhere. Therefore, if the efficiency justification for national uniformity persuades, partial substantive preemption-the federal government sets only minimum standards for surfboards-should be the exception, not the rule. The remaining efficiency arguments for

23. Part 3.2 discusses federalism issues separately. 
partial preemption fail because courts and juries cannot regulate product safety as well as administrative agencies can. Therefore, the states should act only when the federal government has not.

The first efficiency argument for partial preemption implicitly assumes that there is an optimal safety standard for each product. Juries, wherever situated, always apply this standard correctly. When juries never err, federal regulation is unnecessary: tort law alone will induce potential injurers to produce the optimal amount of safety. This result assumes that no potential injurer is wealth-constrained, however. When this assumption is relaxed, a need for minimum standards emerges. To see why, realize that potential injurers will invest in safety until the marginal cost equals the marginal reduction in their expected wealth from liability judgments. Therefore, when a potential injurer's total wealth is less than the social cost of the accidents he may cause, he will invest too little in safety. A federal minimum standard would induce wealth-constrained firms at the low end of the risk spectrum to produce more safety but, because the standard is low, would not affect the safety choices of the affluent firms.

This justification for minimum safety standards is hard to satisfy in practice. There usually is uncertainty as to how juries will apply the vague liability standard (i.e., the risk benefit test) that now obtains for products. When such uncertainty exists, tort law will not necessarily induce firms to take optimal safety precautions. Also, the firms that are the usual defendants in products liability actions commonly are adequately insured.

When firms have sufficient wealth but there is uncertainty in the application of the tort standard, there is a second argument for a federal minimum. ${ }^{24}$ The case rests on two assumptions: while a particular jury can err, juries choose the efficient safety standard on average, and uncertainty in the application of the standard causes firms routinely to undercomply. Part 4 will show that enacting a minimum safety standard induces firms to increase the amount of safety they produce. Hence, if firms do undercomply with the single optimal standard that everywhere obtains (on average), passing a national minimum safety regulation will push firms toward efficiency. This argument is problematic partly because it is unknown whether firms routinely undercomply with current tort law.

24. The analysis here and in Part 4 draws from Kolstad, Ulen, and Johnson (1990) and Craswell and Calfee (1986). 
These arguments for a minimum standard are problematic on a deeper level: they implausibly assume that state courts and juries will choose economically efficient safety standards, either always or on average. To see why this assumption is implausible, it is helpful to describe an efficiency seeking regulator's task. This regulator would choose the product design or safety input that maximized the sum of producers' and consumers' surplus. Roughly speaking, producer surplus is the difference between the product's price and its marginal cost; consumer surplus is the difference between the consumer's utility from use of the product and its price. The sum of these surpluses is the social welfare that a particular design would yield. To choose the regulation - the product design - that maximizes producer and consumer surplus requires the regulator to know the set of technically feasible designs, the cost of producing each design, the price that each design will trade for in the market (which requires the regulator to know how consumer demand responds to price), and how consumer preferences are distributed across product attributes, including safety. Because consumers likely will have different preferences, a regulator who knows all of these things must then solve a complex maximization problem. ${ }^{25}$

Juries are likely to be poorly informed about demand elasticities (how price affects the quantity consumers demand), possible product designs, and their cost and consumer preferences over product attributes and could not estimate solutions to the relevant maximization problem. The regulator, in contrast, will be better informed about the relevant variables because there are economies of scale to regulation. The regulator compares the cost of learning about product designs, production costs, possible future prices, and consumer preferences to the total social gain from producing optimally safe products. The parties in a lawsuit compare the cost of learning about the facts to the marginal increase in the expected value of winning when the jury is better informed. In the usual case, the parties will truncate their research program before the regulator would. Also, regulators are, or could be, trained to solve or estimate solutions to complex maximization problems. Further, as the Introduction indicated, actual juries are not asked to identify the optimal safety standard. Rather they are asked whether the litigated design satisfied consumer expectations or

25. An idea of how complex this problem is can be gathered from Pakes and McGuire (1994, 1996). 
created risks in excess of its benefits. These are not efficiency tests. The point here, in sum, is not that courts are worse than nothing; it is that they are worse than administrative agencies created to perform particular regulatory tasks.

The third efficiency argument for partial substantive preemption holds that tort suits give state courts and juries current information about the effect of safety regulations. For example, a lawsuit may disclose that there are more accidents under a regulation than the federal agency predicted. The common law is necessary because regulations become obsolete. This claim cannot justify current law, however, because courts permit juries to find that recent regulations mistakenly require too little safety (as opposed to having once been correct but having become outmoded).

The argument from current knowledge may support the regnant rule, however, if the common law can force technological change faster than the administrative process can. There are two issues: (1) How quickly does a safety problem become known? (2) How quickly does the state respond? The argument from current knowledge assumes that accidents alone do not convey information; rather, lawsuits are necessary. This claim seems strained as regards products because agencies are directed to keep up; they can impose reporting requirements on firms; and Congress likely will impose significant costs on an agency that neglected what turned out to be a regulatory disaster. Turning to question (2), there usually is a two- to four-year wait in state court from the time a complaint is filed to trial, and then, if the problem is new, there likely will be an appeal. Also, juries may differ, so a firm that loses the first case may want to try again before making a major investment in safety. In contrast, an agency can settle the issue with one rule. The argument from current knowledge is unpersuasive because courts lack a comparative advantage at learning about new dangers and because the common law usually works more slowly than the administrative process.

\subsection{Federalism}

Federalism concerns will support an efficiency case for minimum standards when (1) all citizens are entitled to a certain amount of the relevant good or service; (2) competition among the states may yield equilibria in which the amount is not supplied (for example, states may compete for firms by lowering safety or environmental standards); (3) local val- 
ues may differ as to the appropriate amount to be supplied; and (4) local regulation will not externalize costs to other states. The former two criteria make the case for a federal presence, the third criterion implies that the presence should be a floor, and the last is a constraint on the pursuit of local values. ${ }^{26}$ The first two of the four criteria just listed can justify federal safety regulation. The third criterion-to defer to local values regarding the optimal amount of safety to supply-often is inconsistent with the fourth, however. The relevant local value relates to risk: a state may be more risk averse on behalf of its citizens than other states are. ${ }^{27}$

There are two reasons to think that Congress would not want states to act on this preference. First, states that require products to be made safer than the federal standard may impose costs on the citizens of other states. As said above, if a large state prefers higher safety standards than smaller states and it is impractical for a national manufacturer to make different versions of the product, then the citizens of smaller states may have to consume more safety than they would like. Similarly, if enough small states prefer more safety than some larger states do, then big state citizens may be bound by the preferences of small state citizens. ${ }^{28}$ A state could internalize part of the costs of a strong concern for safety by using other forms of regulation. As examples, a state could run safety education programs or regulate product use. Injuries from off-road vehicles thus could be reduced by restricting the areas in which the vehicles can be used as well as by making the vehicles safer, and bicycle accidents also could be reduced by regulating usage and by requiring riders to wear helmets. These regulations would impose costs on in-state citizens but not on the

26. Some state punitive damage decisions recently have been argued to violate the cost externalization constraint (see Rubin, Calfee, and Grady, 1997).

27. A state also could be less risk-averse. Safety apparently is a normal good, so the citizens of poor states may prefer less safety than the citizens of rich states. This implies that a state should be free, in tort suits, to permit firms to produce less safety than the relevant national standard requires. This possibility is not pursued here because Congress is so commonly taken to set floors, but a fuller treatment of federalism issues would ask whether states should be free to lower national standards as well as to raise them.

28. Recent data suggest that elected state judges attempt to redistribute wealth from out of state firms to in-state plaintiffs, and that this tendency is strongest for poor states (see Tabarrok and Helland, 1999). Since poor states are usually small, if the state courts attempt to redistribute with rulings that firms have supplied insufficient safety and so should be held liable, the possible danger described in the text would be real. 
citizens of other states. In brief, regulating how a product is used and regulating the product itself are partial substitutes. As a general matter, regulating use is less likely to externalize costs to other jurisdictions than is regulating the product. Hence, Congress probably would prefer states with an above average concern for safety to regulate use. This preference would imply full substantive preemption for courts because courts seldom can regulate use effectively (they cannot set traffic rules, for example).

The second reason for Congress to reject partial preemption is that courts are the least representative local institution. A Congress that wanted to defer to local values regarding safety would prefer to have state, county, or city governments make the requisite tradeoffs. The members of these governments are elected more frequently than judges, commonly run in contested elections, and as a consequence of these factors have more contact with voters than either judges or the members of particular juries will have.

To summarize, if Congress is pursuing optimal safety subject to a federalism constraint, it would want full substantive preemption for the state courts in the usual case. To be sure, Congress may enact particular statutes that pursue other goals or are subject to different constraints, and then the case for preemption may weaken. The current preemption rule is stated on a high level of generality, however. When the most widely acceptable safety goal is analyzed on that level, this rule should change.

\subsection{The Argument from Silence Revisited}

The argument to here holds that a Congress pursuing a public purpose could not intelligibly preempt substantively every local legal institution except a state court. ${ }^{29}$ The failure to mention courts in safety statutes

29. Justice Breyer's concurrence in the Medtronics case also makes this point. The statute at issue in the case stated that "no state may establish... with respect to a [medical] device... any requirement... which is different from, or in addition to, any [federal] requirement" (21. U.S.C. $\$ 360 \mathrm{k}(\mathrm{a}))$. Justice Breyer argued:

Imagine that, in respect to a particular hearing aid component, a federal MDA regulation requires a 2 -inch wire, but a state agency requires a 1 -inch wire. If the federal law embodied in the "2-inch" MDA regulation pre-empts the state " 1 -inch" agency regulation, why would it not similarly pre-empt a state-law tort action that premises liability upon the defendant manufacturer's failure to use a 1-inch wire (say, an award by a jury persuaded by expert testimony that use of a more than 1-inch wire is negligent)? The effects of the state agency regulation and the state tort suit are identical. To 
thus should be taken to reflect a judgment in favor of private enforcement of public law, not a delegation to supplement that law. The argument from silence has two other versions that deserve mention. First, courts should read statutes as not preempting in order to force Congress to be explicit about its preferences. The analogy is to the private law canon that documents should be construed against the drafter. This is a weak claim. To see why, suppose that the statute's words would permit any of five possible solutions to a regulatory problem. Then there are two possibilities: (1) the court knows which solution the legislature wanted, or (2) the court does not know. If the court knows, it should read the statute to enact that solution. If the court does not know, then any construction will have the same forcing effect. If, say, the legislature actually wanted solution two (of the possible five), it would be as motivated to speak clearly if the court picked solution one as if the court picked solution three. A commitment to legislative supremacy thus implies that the court should make the best guess as to what the legislature did want or, preferably, should apply the interpretative canon developed in Part 4 below.

The second version of the argument from silence holds that a legislature that continually refuses to settle the issue must prefer the law that has emerged to fill the gap. This argument does not get very far. Congress is not a person whose identity endures through time but a collective entity whose particular make up changes over election cycles. Hence, the question is what the Congress that passed the statute at bar wanted. This Congress may know that past Congresses failed to clarify the preemption issue in contexts other than the one before it. Knowing this, however, would be unlikely to overcome a public regarding Congress's preference for full substantive preemption. This is because there seldom would be a public regarding purpose that could justify the delegation of substantial regulatory power to the state courts to alter federal regulations while at the same time not delegating such power to more competent and representative local institutions.

distinguish between them for pre-emption purposes would give greater power (to set standards "different from, or in addition to," federal standards) to a single state jury than to state officials acting through state administrative or legislative lawmaking processes. Where Congress likely did not focus specifically upon the matter, ... I would not take it to have intended this anomalous result. (518 U.S. p. 504) 


\section{A Structural Rule for Resolving Unclear Cases}

When doubt remains as to what the legislature wanted, a court should choose that meaning that would be easiest for the legislature to correct if the reading is erroneous. Part 4 develops and applies this claim in two steps. First, it introduces the problem of "policy drift." This problem exists when a court or agency can choose a policy that the legislature either (1) cannot reverse though the legislature wrote the governing statute to implement another policy or (2) can reverse but at the cost of choosing a policy other than the policy that animated the governing statute. The policy drift problem is regarded as serious in the relationship between Congress and the federal agencies. Part 4.1 argues that the problem is acute in the relationship between Congress and the state courts. Part 4.2 then argues that a Congress that thought about the matter would want state courts to use interpretative strategies when construing federal safety statutes that minimize the risk of policy drift.

\subsection{Policy Drift}

Consider a simple model of the relation between the Houses of Congress, the President, and an administrative agency that is created to regulate product safety. ${ }^{30}$ The agency's rules are subject to judicial review by federal Courts of Appeal. In the model, the agency can have independent policy preferences, but, for convenience, the federal courts are assumed to enforce Congress's intent.

A product safety regulation reflects a tradeoff between safety and product amenities. For example, a very safety conscious agency will require bicycles to be quite sturdy, though such strong bikes may have inferior handling characteristics and lack style. Legislators and the President are assumed to know little about particular products. These decisionmakers, however, have preferences regarding which criteria-safety, handling, style - the agency should consider, and also have preferences regarding the possible rankings of these criteria. The set of technologically feasible product attribute combinations and attribute rankings is denoted $X$. Denote House member $i$ 's preferred policy as $H_{i} \varepsilon X\left(H_{i}\right.$ belongs to the set of

30. The modeling strategy used here and the results in the relevant literature both are explained in Hammond and Knott (1996). The analysis omits legislative committees but adding them would not change the results. 
possible combinations and ranks, say, handling first, then style with safety last). The conditions on voter preferences set out in Part 2 (complete, consistent, etc.) imply that the member's utility declines monotonically as the House's policy choice moves away from her ideal point $H_{i}$ in any direction in policy space. Similarly for members of the Senate and for the President.

The "win set" of a particular policy $x$ in the feasible set $X$ is the set of policies that majority defeat $x$ in the relevant legislative body. Denote the win set for the House $W_{H}(x)$. The win set necessarily is empty for policies that are in the core because no policy can majority defeat a core policy. Figure 1 describes the ideal points of a five-member legislature. In the Figure, $W_{H}\left(H_{3}\right)=\Phi$ because $H_{3}$ is the only core policy: a move away from $H_{3}$ in any direction in policy space would be vetoed by a majority of three legislators. ${ }^{31}$ In contrast, $W_{H}(s q)>0$ because $s q$-the status quois outside the core. The safety policy that $H_{3}$ summarizes would majority defeat $s q$, so the assumed legislature would enact $H_{3}$.

31. The symbol $\Phi$ denotes the empty set.

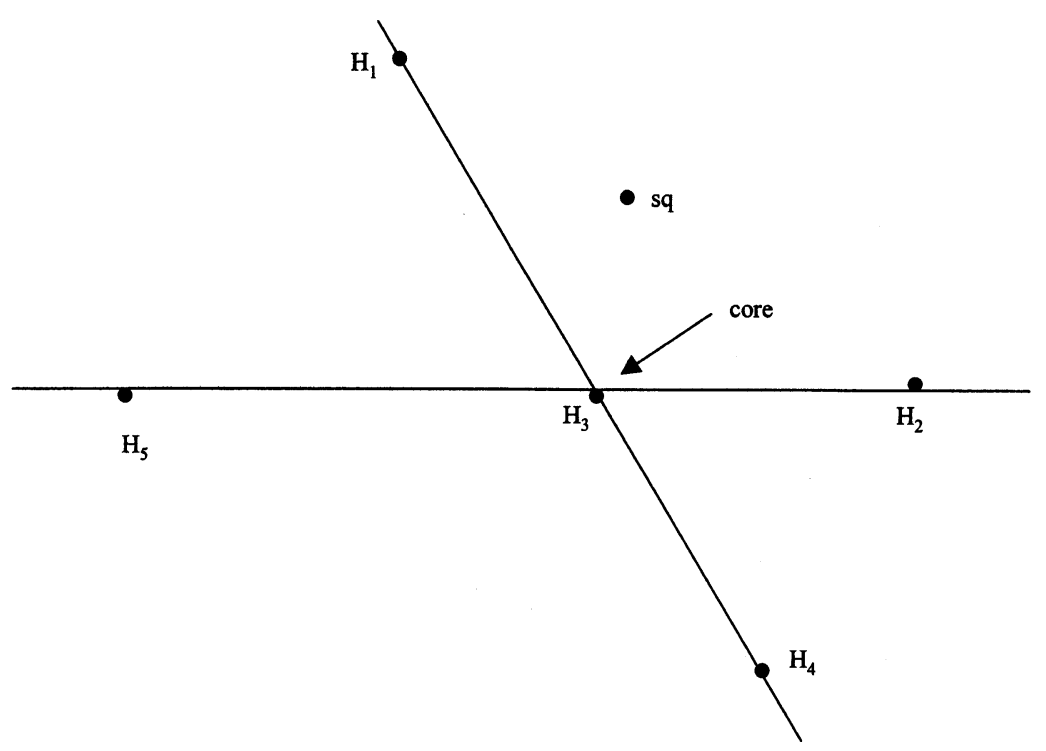

Figure 1. 
The President will veto any policy that leaves him worse off than the status quo. Consider a policy proposal $x$. When there is no policy that a majority of the House, a majority of the Senate and the President would prefer to $x$, then $x$ is in the House/Senate/President core. Denote this core HSP.

Turning to the problem of policy drift, an administrative agency with independent policy preferences will have autonomy if it can choose a policy that the legislature could not reverse. Assume that the legislature can monitor the agency costlessly. ${ }^{32}$ Nevertheless, if the HSP core has more than one element, the agency may have autonomy. To pursue this possibility, let the status quo be no automobile regulation and refer to Figure 2. The triangle labeled HSP is the House/Senate/President core. The status quo, $s q$, is not in the core, thus implying that regulation is politically feasible. The dark area is the win set for the status quo, which is the set of regulatory safety/amenity combinations that Congress and the President prefer to no regulation. The dark area is denoted the agency's permissible policy set, or $P S$, because the policies in it are acceptable to Congress. Hence, $W_{H S P}(s q)=P S_{s q}$.

An agency with independent preferences and the power to initiate policy could enact a regulation that required the safety/amenity combination denoted $x$ or the combination that is denoted $y$. Because $x$ is outside the HSP core, it is unstable. The cross-hatched area is the win set for $x$ : starting from $x$, Congress and the President could agree on the set of safety/amenity combinations that are in the cross-hatched area. The agency could not be reversed, however, if it chose the safety/amenity combination denoted $y$ because $y$ is in the HSP core. Recall that no policy majority defeats a core policy. This analysis teaches two lessons. First, even when an agency chooses a policy that Congress can overrule, Congress sometimes cannot restore the policy that the regnant legislative coalition originally preferred. ${ }^{33}$ Second, agency policy choices can be irreversible. That Congress sometimes cannot restore its original policy

32. Agencies can have autonomy when legislative oversight is costly to exercise. Lobbyists can facilitate the legislature's oversight role by providing information about what the agency is doing. The seminal analysis is McCubbins and Schwartz (1984). A more recent treatment is Epstein and O'Halloran (1995).

33. McNollGast also obtained this result, although in a model with a twodimensional choice problem (McCubbins, Noll, and Weingast, 1989). 


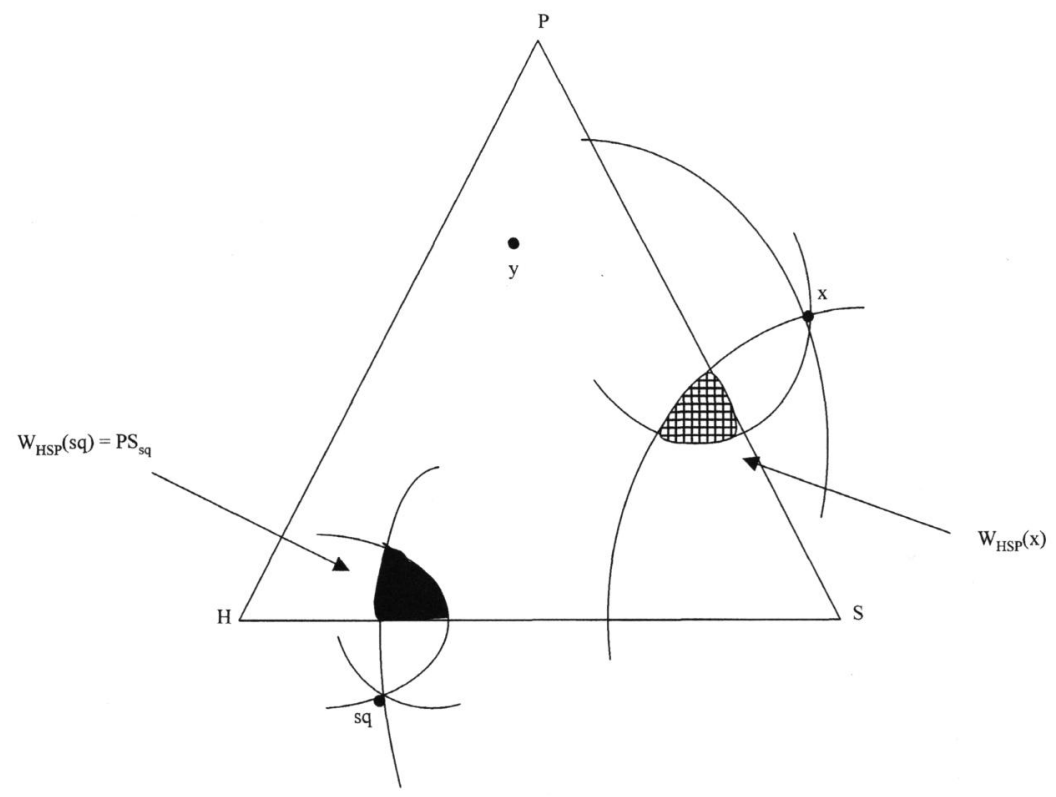

Figure 2.

choice and sometimes cannot reverse an agency at all is the policy drift problem.

As is becoming recognized, legislatures attempt to constrain administrative policy drift. There are four methods. The first is legislative oversight: the legislature monitors the agency's performance, holds hearings that are costly for agency members to attend, and through budget control rewards compliant behavior and punishes noncompliant behavior. The second method of control is to influence agency appointments. ${ }^{34}$ Third, the agency can be required to follow a set of administrative procedures. These procedures control who can appear before the agency, how the agency must make rules or decide cases, and the like. Controlling procedure sometimes can control substance. The final method of control is judicial review. The legislature defines the set of core policies from which the agency cannot deviate and instructs the appellate courts to constrain the agency to the policies in that set. Referring again to Figure 2, a court

34. McNollGast argues that these two methods have limited utility (McCubbins, Noll, and Weingast, 1987). 
that is a faithful agent of Congress will strike any agency policy choice that is outside the dark area $P S_{s q}{ }^{35}$

This analysis shows why the typical Congress would be particularly concerned with the possibility of state court policy drift. Contrary to the assumption above, it is costly for Congress to monitor federal agencies, and it may be more costly for it to monitor the state courts. Some jury verdicts are opaque; they only award or fail to award money. There also are many verdicts and 50 states. On these facts, it likely is difficult for Congress to reconstruct the product safety and amenity combinations that state law actually is requiring firms to meet. High congressional monitoring costs confer substantial practical autonomy on the state courts to regulate products. ${ }^{36}$

The more serious problem was just developed: state tort law could require firms to produce safety and amenity combinations such that: (1) Congress could overrule the state courts but could not reenact any of the safety/amenity combinations that are in the permissible set $P S_{s q}$; or (2) Congress could not affect a state induced result at all because the result requires safety/amenity combinations that are in the HSP core but outside the permissible set. In either event, a Congress that understood what juries were doing would have its will frustrated. Congress also cannot use the indirect methods of control to deter state court policy drift. Congress cannot influence state court appointments, procedures, or budgets, and the federal appellate courts do not review state tort law judgments. That Congress cannot exert indirect control over the state courts, as it can over federal agencies, implies that a Congressional preference exists for the state courts to use the interpretative strategy urged here: these courts, that

35. Mashaw, supra note 14, remarked (at 193) that judicial review should function in this way: "... from a normative perspective, the external environment of rule making should be structured to force administrative policy within the half lens [the PS set in Figure 2]. That is the democratically approved bargain embodied in the legislation... Judicial review... should have the same purpose." Similarly, Sunstein, supra note 7, observes (at 149) that delegations to agencies "have been allowed largely on the assumption that courts would be available to ensure agency fidelity to whatever statutory directives have been issued." Congress's problem respecting policy drift is more complex when the federal courts have policy preferences of their own. Interesting analyses are Spiller and Tiller (1997) and Ferejohn and Weingast (1992).

36. This difficulty may be partly mitigated by "fire alarm" oversight: affected interests have an incentive to tell Congress what the states are doing (see authorities cited supra note 32 and also Lupia and McCubbins, 1994.) 
is, should interpret statutes in ways that facilitate the ability of Congress to correct interpretative errors. Part 4.2 shows how this general interpretative strategy applies to the regulatory compliance defense. ${ }^{37}$

\subsection{Controlling Policy Drift}

It is harder for Congress to correct an erroneous judicial interpretation that it intended to enact a minimum safety standard than it is for Congress to correct an erroneous judicial interpretation that it intended to enact a national standard. To see why, realize first that Congress legislates against a background of state tort law. The effect of a new safety statute on a firm's behavior thus requires an initial analysis of how unmodified state law influences the firm's safety decisions. Part 4.2 begins with this analysis, then shows how a federal minimum or national safety standard affects the amount of safety firms will produce, and last shows how one type of judicial error is easier for Congress to correct than the other.

Products Liability law alone applies in the no regulation world. Denote as $x$ a particular safety level that a firm may produce. This safety level will affect two probabilities. The first is the probability that an accident will occur, which is called $p(x)$. If the firm is held liable for an accident, it will expect to pay damages of some amount $d_{j}(x)$, where $J$ indexes all possible juries and $d_{j}$ is the award that jury $j$ will make. Thus, the expected value of a successful judgment against a firm that is sued and loses is $j(x)=p(x) \bullet d_{j}(x)$. The second relevant probability concerns whether a firm that is sued will actually be found liable. Current law holds that a product is defectively designed if it creates risks in excess of the benefits it yields. This is a negligence test, and there is commonly

37. As the Introduction indicated, the state courts would apply this strategy by treating federal statutes or regulations as national standards. If a regulation is at issue, however, there is a prior question whether the regulation itself is in the permissible set or reflects policy drift. If the latter, should the state courts apply a standard that Congress itself would not want? There are two answers to this question. First, when Congress has given sufficient direction to federal appellate courts to enable these courts to confine agencies to the permissible set, the state courts, on the arguments to be made below, should act as would a federal appellate court. That is, they should apply the safety standard that Congress prefers. Second, when the PS set is difficult for any court to determine, so that courts are unsure whether the agency drifted, both federal and state courts should apply the regulation the agency chose. This is because Congress is better equipped than the courts to detect deviations and to use indirect methods of control to deter them. 
uncertainty as to how particular juries will apply a negligence test. In an uncertain world, the amount of safety the firm chose-the level of $x$-will affect the likelihood that a jury will find it liable, but will not conclusively determine that likelihood. Consequently, the firm will predict the second probability by estimating the mean level of safety that the legal system likely will require it to meet, and the variance around that mean. Denote $a_{j}(x)$ as the probability that a jury will hold the firm liable given the level of safety it chose. ${ }^{38}$ It also is costly for the firm to produce safety. If $c(x)$ is the cost to the firm of producing safety level $x$, then the firm's total expected safety costs are $E(S)=c(x)+\Sigma a_{j}(x) j(x)$. The firm will choose the $x$-the safety level-that minimizes $E(S)$, its expected safety cost.

Such a firm may produce more safety than the mean of the safety distribution - the average level of safety the legal system requires-or less. To see what the firm will do, realize that uncertainty as to the jury standard that will actually be applied has two possibly offsetting effects. The first effect of uncertainty is to induce the firm to undercomply with the expected jury standard. There is a positive probability that the standard the jury in an actual case would choose would be lower. The larger the uncertainty (in technical terms, the greater the variance) around the mean jury standard, the smaller the probability that a noncomplying firm will be held liable. On the other hand, if a jury's application of the risk benefit test is partly a function of how much safety the firm produced, and there is relatively little uncertainty in application of the standard, then the firm has an incentive to overcomply. To illustrate, let the expected jury standard require a platform to hold $120 \mathrm{~kg}$ of weight and suppose that the probability of being held liable falls sharply as the firm increases platform strength above $120 \mathrm{~kg}$. Then the firm might make the platform

38. For technical readers, let $t(x)$ be the firm's probability distribution around the legal standard. Assume that $t(x)$ is a continuous probability density with support $[0, \infty]$. Then the probability that the firm's precaution level $x$ will be found below the legal standard of care is

$$
a_{j}(x)=\int_{x}^{x_{\max }} t(x) d(x) .
$$

As $x$ increases-the firm produces more safety-the value of the integrand declines: the firm will assign a lower value to the probability of being held liable. The analysis here ignores the possibility that an accident victim also will be negligent. Considering this possibility would not affect the conclusions. 
hold more than $120 \mathrm{~kg}$. At $120 \mathrm{~kg}$, the marginal reduction in the firm's expected accident cost (due to the marginal reduction in the probability of being held liable) would exceed the marginal cost of producing more safety.

The second factor affecting what safety level the firm will produce is the marginal cost of producing safety around the expected jury standard. If adding $5 \mathrm{~kg}$ of strength to the platform is very expensive, then even a large decrease in the probability of liability may not justify the added safety expense. But if the marginal cost of producing more safety than the mean expected jury standard requires is relatively low, the firm likely will overcomply with the standard. This is because the marginal cost of safety would be lower than the marginal reduction in the firm's expected liability cost in the neighborhood of the standard.

A firm is unlikely to produce safety at either extreme point. The minimum such point would require a safety level of zero: the product is maximally unsafe. A firm would produce the lowest safety level only if uncertainty respecting application of the jury standard is very great (so that there is a great gain to undercomplying by the maximum amount) or if the marginal cost of producing more safety than the minimum requires is very large (so that there is a great cost to producing any safety at all). In the usual case, firms will produce more safety than the minimum that a jury might possibly permit. The other extreme point would require the firm to produce so much safety that any more would alter the character of the product. A car would become a tank. The marginal cost of producing this much safety would likely swamp the marginal reduction in the expected value of being held liable in tort.

Now consider Congress (or an agency) that is choosing a safety regulation that it expects the courts to interpret correctly. Congress could choose a minimum standard, denoted $x_{\min }$, or a national standard. A Congress that wanted to set a floor would not approve a safety standard that equaled the technologically feasible maximum, $x_{\max }$ : for then, all firms would produce the safety level $x_{\max }$. Picking the highest feasible standard is inconsistent with an intention to set a floor. A statute (or regulation) that set $x_{\min }<x_{\max }$ would have three effects: (1) no firm would produce less safety than $x_{\min }$; (2) all firms would produce more safety than they had been producing before the legal change; and (3) firms could choose among designs that embodied the minimum amount of safety or more. 
The second effect requires more discussion. That the federal government selected a product for national regulation likely will induce a court or jury to suppose that the product is more dangerous than would be thought had there been no regulation. A firm that anticipates this reasoning will itself reason that the probability of being held liable at any particular safety level $x$ has increased. Returning to the equations introduced above, if the firm's new probability of being held liable is $a_{j(\min )}(x)$, then $a_{j(\min )}(x)>a_{j}(x)$. The firm's new problem will be to choose that $x$-the safety level-that minimizes $E\left(S_{\min }\right)=c(x)+\Sigma a_{j(\min )}(x) j(x)$. Notice that $E\left(S_{\min }\right)>E(S)$ : the expected cost of safety to the firm if it produces a particular safety level $x$ is higher after Congress requires a minimum level of safety than before, because the firm's probability of being held liable if it produces safety level $x$ is higher. In consequence, the marginal gain to the firm as it begins to increase the safety level above $x$ will be positive. The higher the minimum level of safety a statute or regulation requires, the more safety the firm will be induced to produce. ${ }^{39}$

A Congress that intends to require only a minimum level of safety thus intends to produce the three effects noted above: no firms below the minimum, an increase in the general safety level, and firms with discretion to choose the safety/amenity mix. A Congress that intends to enact a national standard also wants firms not to produce less safety than the standard requires. This Congress, however, knows that it has withdrawn considerable discretion from firms for two reasons. First, a national stan-

39. Again for technical readers, passing a minimum safety standard truncates the distribution of safety levels that a jury could permit at the lower end (because the firm is liable with certainly if it produces less safety than the statutory minimum). As a result, probability mass is transferred to the part of the distribution above the minimum, increasing the likelihood that the firm will be held liable for any safety level $x$ that the firm produces. For a firm with convex costs, when the first order condition for $E\left(S_{\min }\right)$ is differentiated totally with respect to the regulatory safety level $x_{\min }$, then unsurprisingly the result is

$$
\frac{d x}{d x_{\min }}>0
$$

As the minimum regulatory safety level $x_{\text {min }}$ increases, the firm will produce more safety. Although there is little direct evidence for this result, it has recently been shown, in the FDA context, that increased Congressional oversight of agencies increases regulatory compliance by firms. The oversight is taken as a signal of possible increased agency enforcement activity or more rulemaking (see Olson, 1999). When an agency actually adopts a new safety rule, this may signal to firms possible increased enforcement activity by it and by private parties. 
dard will require more safety than the minimum, thereby shrinking the set of safety/amenity combinations that a firm can produce. Second, a court that enforces the national standard will exculpate firms that meet it from liability. A firm thus could not reduce its probability of being held liable by producing more safety than the law requires. These reasons suggest that firms likely will produce safety/amenity combinations that are in the neighborhood of the safety level in the statute or regulation. Because Congress can anticipate this, it is safe to suppose that a House/Senate/President majority existed for the regulatory safety level that was enacted. On the information given here, however, it is not certain that the enacted choice could majority defeat every other technologically feasible safety level that Congress could have required firms to satisfy.

Turn next to the possibility of judicial error. A court can make either of two mistakes: to interpret a national standard as a minimum, or to interpret a minimum standard as national. In analyzing these errors, it will be helpful to denote the set of core points differently than in the model of Part 4.1.

The vertical axis in Figure 3 represents the safety level for a product; the horizontal axis represents the amenity level. The Figure assumes that the core is not a singleton: that is, there is a set of safety/amenity combinations for Congress and the President none of which can majority defeat the others. The curve $N$ in Figure 3 represents a set of possible core points.

Begin with the error of treating a national standard as a minimum and let a statute direct the federal agency to enact regulations that reflect the safety/amenity combination denoted $b$. If courts treat this regulatory level as a minimum, then unless Congress set the level at the technological maximum ( $x_{\max }$ in the analysis above), firms will produce more safety than they had been producing. Points $a, c$, and $d$ reflect possible safety/amenity combinations that state law could induce firms to produce: all of these require more safety than the statutory point $b$ does. Congress could reverse the combinations that $c$ and $d$ reflect but could not reverse any combination on the curve $N$, such as point $a$; for all points on the curve above $b$ also are in the core. Figure 3 thus illustrates the likely fact that the set of safety/amenity combinations that Congress can pass will not necessarily majority defeat all of the safety/amenity combinations that state courts could induce firms to produce, when the state induced combina- 


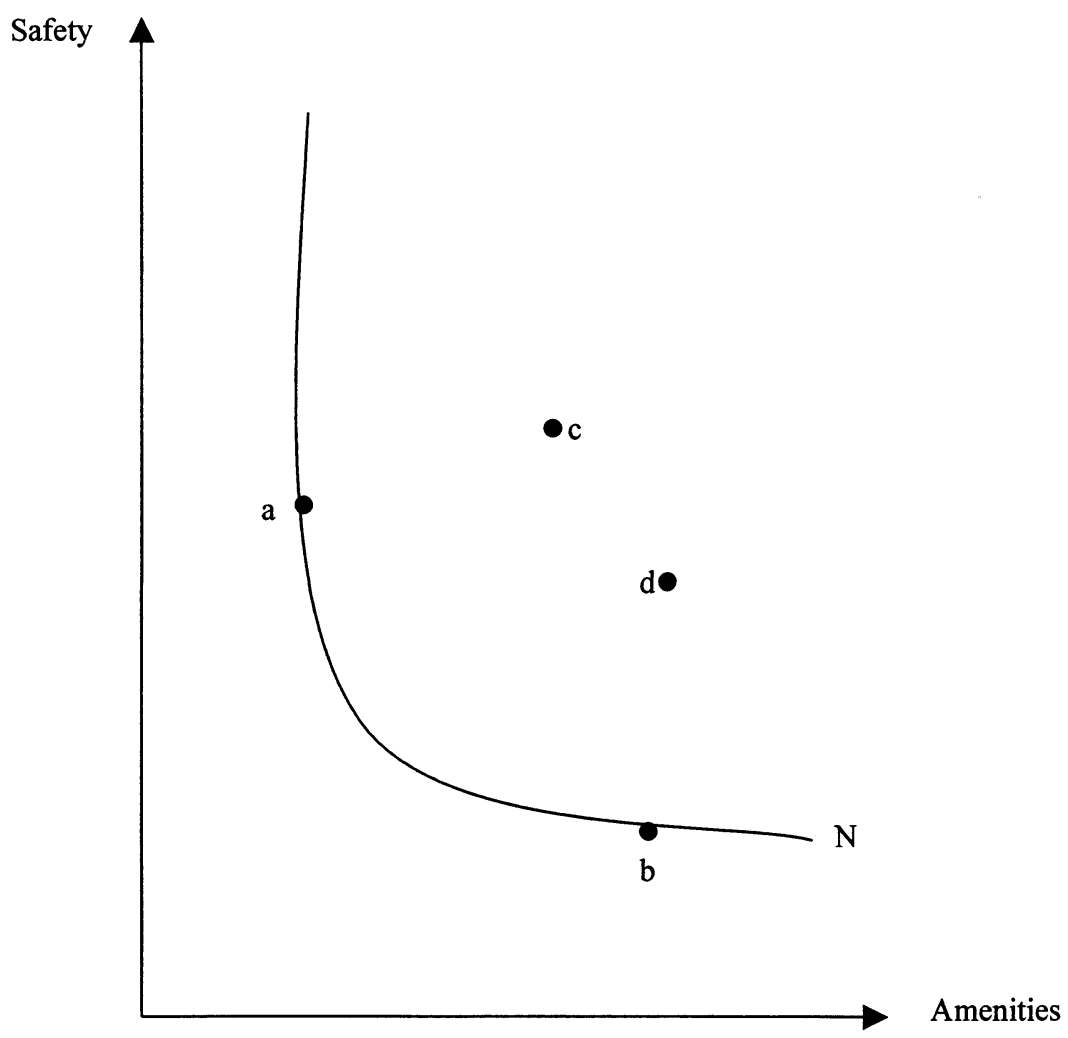

Figure 3.

tions require more safety than Congress did. As a consequence, Congress sometimes cannot correct erroneous state court statutory interpretations that take Congress to want a minimum standard when Congress actually wanted a national standard.

Next consider the judicial error of finding that Congress wanted a national standard when it wanted only a floor. A state court that read Congress as setting a national standard would defer to that standard: it would hold firms liable that did not meet it and exculpate firms that did. If point $b$ in Figure 4 reflects the safety/amenity combination in the statute (or regulation), courts will hold firms to point $b$. It was shown above that when Congress knowingly enacts a minimum, it intends to increase the average safety level above that minimum and to give firms discretion to 


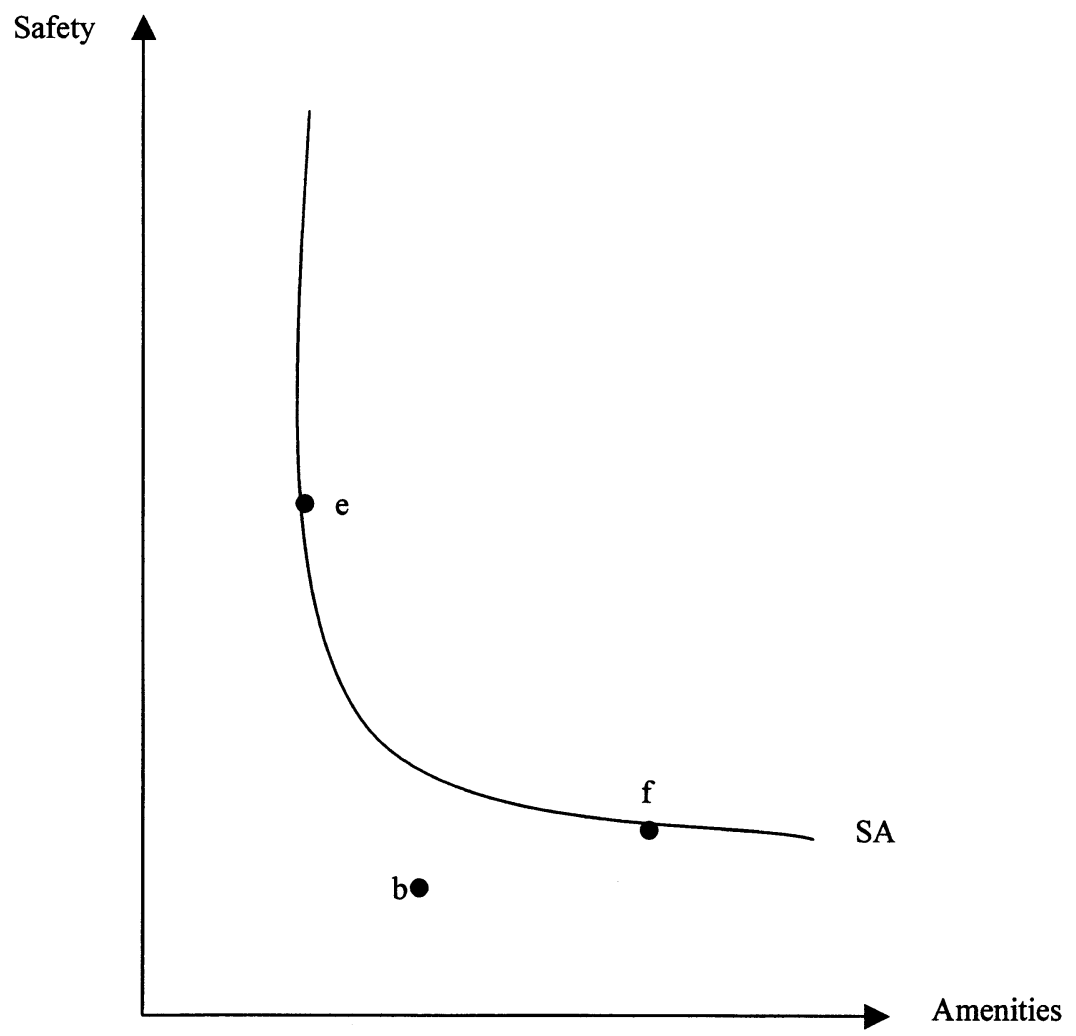

Figure 4.

choose safety/amenity combinations. The SA curve in Figure 4 reflects a possible set of safety/amenity combinations that Congress would expect the statutory minimum reflected in point $b$ to induce (if courts correctly interpret the statute to require only a minimum). The part of the SA curve between $e$ and $f$ describes the set of safety/amenity combinations that would majority defeat point $b$ if Congress were choosing a national rather than a minimum standard.

This analysis has an important implication: when Congress wants state courts to treat safety regulations as minima, the win set for a point such as $b$ seldom will be empty. That is, there very likely will be at least one safety/amenity combination that the national government could pass that would require more safety than the safety/amenity combination that the 
state courts are requiring firms to produce, when the state courts wrongly find that Congress intended to enact a binding national standard. Again, this result obtains because a Congress that wants to enact a minimum expects to induce firms to produce more safety than the minimum. Therefore, when the state courts wrongly hold that a national standard was meant, Congress either will amend the statute to make clear to the state courts that only a minimum was intended or it will raise the statutory minimum. Since Congress cannot deter state law interpretative mistakes with indirect methods of control, such as budgetary pressure, this "risk of error" analysis implies that Congress prefers the state courts to interpret federal safety regulations to set national rather than minimum standards. ${ }^{40}$

Finally, it may be observed that Congress can reverse noncore policies, so that state court interventions will not produce policies that lie outside

40. Congress sometime uses a third rule called a "safe harbor." This rule will exculpate firms that comply, but does not necessarily hold firms liable that do not; rather, the behavior of noncompliant firms is adjudicated case by case. The interpretative rule that courts now use, which assumes that Congress intended a minimum standard, would entirely vitiate a safe harbor rule were one intended, for the current rule holds liable all noncompliant firms and some compliants firms, thereby strongly overdeterring the relevant behavior. Assuming that Congress intended a national standard preserves the feature of the safe harbor rule that exculpates compliant firms, but also overdeters because it automatically holds liable some firms that a case-by-case inquiry would excuse. In fact, if Congress could choose any of the three rule types, a judicial assumption that Congress meant to choose a safe harbor might be best. This interpretative strategy would not strongly overdeter and will produce less safety than either a national or a minimum standard. As shown above, it is easier for Congress to correct mistaken interpretations that suppose it to want too little safety than to want too much. State courts should not resolve uncertain cases by taking Congress to have enacted a safe harbor, however, because Congress seems not to use this rule in the safety area.

The argument in text implicitly assumes that Congress lacks rational expectations. To justify this assumption, realize first that if $B$ will raise any standard that $A$ enacts, then $A$ will enact a standard that is below its ideal point. A could be regarded as the Congress, but there are $50 \mathrm{Bs}$ - the state courts-and each of them could choose a different safety level. Also, the level that is chosen in a law suit can be a function of the particular facts. Thus, unlike in the two-person case, Congress could not easily predict the state courts' responses to its statutes. Consequently, Congress would have difficulty gaming against the state courts and would prefer to enact its ideal point and have it respected. 
the maximal set. This may suggest that the current interpretative rules are normatively defensible. The suggestion should be resisted because Congressional procedures determine which core points are enacted as statutes. The procedures, in turn, are designed to enable Congress to implement its substantive preferences over a range of areas through time; that is, the procedures help to ensure that Congress will enact a certain set of laws in general and not other laws. As an illustration, a recent study of how various Congresses voted on the question whether the Senate should retain its unlimited debate rule concluded: "The overwhelming importance of the policy positions of senators in voting for reform suggest that, on the whole, senators' views about the [procedural] rules are determined by the implications of those rules for the policy choices of the Senate" (Binder and Smith, 1998). Hence, an interpretative rule that directs the state courts not to search for legislative intent but rather to choose the policy they prefer because the final outcome will be in the core would deprive the national government of much control over the setting of policy generally. ${ }^{41}$

\section{Capture}

The argument in Parts 3 and 4 supposed Congress to be pursuing a public purpose. The current preemption rule, however, is partly justified by a contrary assumption, that Congress commonly is captured by private interests. Part 5 will claim that courts should not use the capture concept as a justification for altering federal safety regulations.

The analysis will focus on possible capture of the Congress because Congress creates the regulatory criteria that govern the agencies, and also because Congress sometimes can reverse an agency action and otherwise

41. A minority of federal statutes that do not discuss tort law sometimes explicitly will recite that the states' common law may continue to function in the field. An allocation of authority under which the power to set safety standards is delegated to an administrative agency and the power to adjudicate compensation is delegated to a court best uses the relative expertise of the two institutions. In light of the arguments in this article, then, statutory references to the common law are best taken as making clear that courts are not preempted institutionally from using tort remedies to sanction statutory violations. 
exert indirect control over agencies. ${ }^{42} \mathrm{~A}$ capture claim can be made in a weak or a strong form. The weak form applies to the regulation of a single product. It holds that there is a normatively desirable safety level that the product should meet. In consequence of political failure, Congress permitted an agency to allow firms to fall below this safety level. Therefore, regulations that the agency enacts probably will require too little safety. A court in a products liability suit thus is justified in treating the regulatory safety level as a floor that state tort law is free to raise. ${ }^{43}$ The strong form of a capture claim holds that the political failure affecting the regulation of the particular product is general. It is the strong form of the capture claim that partly sustains the current interpretative rule; the courts treat all regulatory levels as floors. Both forms of the capture claim are in the

42. In addition to the ability of Congress to affect agency output, there is an unresolved dispute in the literature regarding whether Congress is easier to capture than federal agencies are. One the one hand, it is legal to give legislators money (campaign contributions) but it is not legal to give agency personnel money. This implies that lobbying before agencies will only be informational (the lobbyist provides information and attempts to persuade). Congress thus seems easier to capture than an agency. On the other hand, agency decisions generally have less visibility than legislative decisions. Thus, it may be easier to bring whatever influence an interest group has to bear on an agency. This implies that agencies are easier to affect. Given this uncertainty, little generality seemingly is lost by analyzing the possible capture of only one of these institutions.

43. Ausness, supra note 1, puts this claim well (p. 1238): "Tort liability offsets... flaws in the regulatory process by encouraging manufacturers to exceed federal safety regulations when it is cost effective to do. This incentive will be foreclosed if state tort claims are preempted by agency action." A efficiency based capture claim may founder over the difficulties discussed in Part 3.1: the state courts have difficulty identifying the efficient safety level. In addition, the likelihood of capture is negatively related to the heterogeneity of the regulatee universe. A single industry will have less difficulty coordinating on a strategy to influence regulation than a number of industries will have. Hence, Congress or an agency has more freedom to pursue the public interest when regulating a diverse group of firms. In addition, there is substantial evidence that Congress overregulates as well as underregulates (see Frailberg and Trebilcock, 1998). This evidence together with firm diversity calls into question the monism of current tort law, which supposes that business generated capture is equally likely for all safety regulations. Finally, state courts and agencies also can be captured. A complete defense of the capture justification that helps support current law thus would be comparative, showing that state legal institutions are less subject to capture than federal institutions. This showing has not been made. Part 5 focuses on more basic problems with the capture concept than the concerns raised in this note. 
genre of arguments that statutory interpretation should attempt to redeem defects in the political process. ${ }^{44}$

These arguments resonate because organized groups commonly affect political outcomes. The task for a court doing statutory interpretation, however, is to distinguish between statutes or regulations that are a product of the usual political processes and those that were the product of inappropriate pressures. Only the latter require interpretation to improve the law. Part 5 will argue that political processes are not well enough understood to permit courts to draw the requisite distinctions when acting on the weak form of the capture objection (which evaluates capture case by case). If this is so, the strong form also is nonjusticiable.

\subsection{The Capture Concept}

Capture claims should be analyzed similarly to preemption claims, in the sense that a useful capture discussion cannot get off the ground unless the discussants first agree on the substantive goal that the relevant legal institution is supposed to pursue. This is because an institution is "captured" when it is prevented from doing what it would do in a better world.

44. Eskridge, supra note 6 (at 159), is illustrative:

A related dysfunction is Congress's tendency to delegate policy decisions to agencies, which might then be "captured" over time by regulated groups or other interests. ${ }^{87}$ Agency capture happens when the regulated group is significantly better organized than beneficiaries who are widely distributed throughout the polity and whose diffusion and numbers make them less likely to organize politically.... Statutory interpretation can operate (at least at the margins) to keep the implementation process open to critical perspectives and even to represent the voice of forgotten beneficiaries.

In a similar vein, Farber and Frickey, supra note 7 (at 116), say, "The goal [of reformminded courts] would be to tip the legislative process towarrd ideology and structureand thus, toward legislative ability to formulate public policy-and away from legislative capture by special interests and incoherence." See also Gillette and Krier (1990): "... the problem of asymmetric access [because of differential coalition costs] suggests that agency decisions would tend in the direction of producer interests, and thus toward too much public risk [imposed on citizens]." A criticism of using statutory interpretation to ameliorate political process defects is Elhauge (1991, p. 31). 
For example, if Congress should require agencies to create efficient safety regulations, then Congress is not captured unless the political process has caused it to permit agencies to create inefficient safety regulations. ${ }^{45}$ Following the practice in Parts 3 and 4, this part assumes that a Congress free from invidious political pressures would want optimal safety regulations. ${ }^{46}$

Realizing that a capture claim necessarily presupposes a substantive norm exposes two difficulties. The first difficulty runs to relevance. If the enacting Congress would ideally have pursued efficiency, there apparently is no need for a court to ask whether process defects infected a particular regulation: the court instead could enforce the regulation if it was efficient and ignore it otherwise. ${ }^{47}$ The relevance difficulty is not conclusive, however, because outcomes can be hard to evaluate directly. In the area of economic regulation, it thus is customary to focus on factors that correlate negatively with efficiency. As an illustration, it is enough in antitrust law to show the existence of a cartel; the court need not evaluate the prices that the cartel charges. Similarly, it may be enough here to show the existence of invidious political factors that prevented the Congress from pursuing a desirable goal.

This raises the second difficulty with the capture concept, that of causation. Suppose that Congress intended to enact a national safety standard. That the statute was passed under the legally prescribed procedures entitles it to some presumptive weight; it is the law. Also, the statute was passed by a democratic majority and signed by a democratically elected President. A state court that feels free to vary the statute because a higher safety standard seems best to it thus encounters both federalism and countermajoritarian difficulties. These difficulties would be avoided if (1) the

45. This insight is not original but is often ignored. See Levine (1998): "Calling a regulator 'captured' usually implies taking positions on intellectual choices of which the user is unaware"; Elhauge, id. p. 49: "condemning the political process because of interest group influence is indistinguishable from condemning the political process for producing outcomes the condemnor dislikes on independent normative grounds." See also id, pp. 48, 60 .

46. As will appear, the same points could be made if Congress had redistributional or other normative objectives.

47. Elhauge (1991) apparently believes that decision makers should apply substantive norms directly to statutes rather than evaluate statutes by the indirect means of assessing process defects. 
state courts withdraw presumptive legitimacy only from safety statutes that were passed on account of invidious political factors, and (2) these courts implement the result that Congress would have enacted had the invidious factors been absent. ${ }^{48}$ To satisfy these inquiries requires a causal theory, but no such theory is apparent. This is the causation difficulty.

\subsection{An Analysis of the Causation Difficulty}

Begin with the usual capture story, which focuses on the relative ability of groups to influence the legislature. This focus creates a ubiquity concern. Political markets are said to fail in consequence of concentrated costs and diffuse benefits or concentrated benefits and diffuse costs. In this story, when a proposed regulation would impose costs on a cohesive group, the group perhaps could subvert the regulatory scheme. When regulation would create benefits for a cohesive group, the group may cause the regulation to be passed in a form that gives them disproportionate gains. The ubiquity concern is that Congress seldom passes laws without the support of cohesive, politically influential groups. Also, many of the people who may be adversely affected by a statute often play no role in its adoption. ${ }^{49}$ Thus, almost every federal statute is the product of capture in the concentrated costs/concentrated benefits sense. It cannot follow that the state courts are entitled to withdraw presumptive legitimacy from all of them because a capture theory is supposed to tell the courts how to distinguish good laws from bad ones. ${ }^{50}$ Therefore, the search must be for more particular causal factors.

48. An analogous need apparently exists in other areas. See Kreimer (1984): "In order to infer [for purposes of judicial review] that a decision was tainted by an impermissible purpose, the court must determine what the government would have done in the absence of that purpose. But in order to make that determination, the courts must have a model of the way that a proper government would function."

49. Mashaw has remarked that "all potential groups do not form, and those that do have significant power in the legislative process" (supra note 14, pp. 55-56).

50. This point has been made before. In analyzing Muller v. Oregon, 208 U.S. 412 (1908), which upheld a statute that set maximum hours women could work in factories and laundries, Mark Tushnet remarked:

In the real world of politics, the statute in Muller was the product of a complex alliance among labor unions, social workers, ideologues, and the like.... If an augmented [constitutional] theory allowed this sort of alliance to qualify as a systematic distortion of the political process, it is hard to see what would not count. Constitutional theory must resist that conclusion. (Tushnet, 1988; see also Spitzer, 1988) 


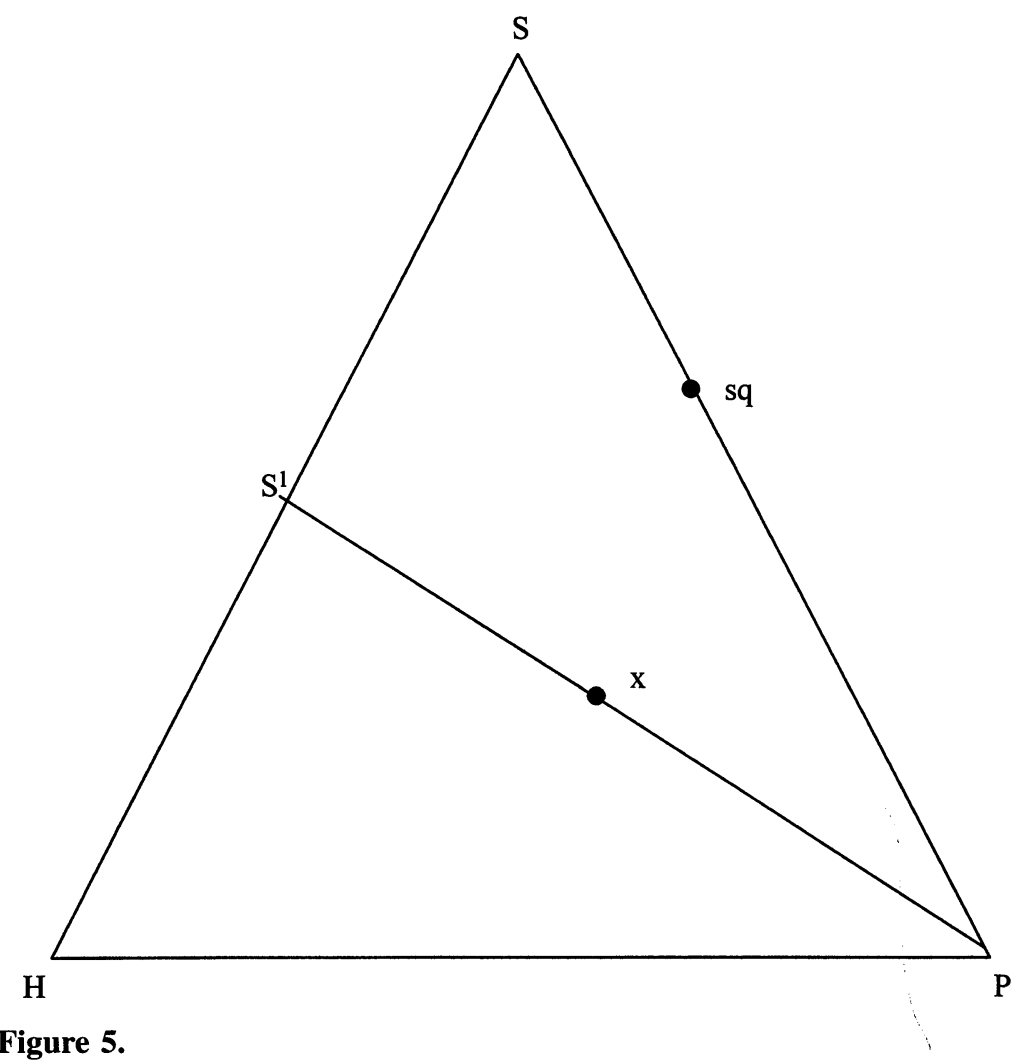

The model of automobile safety regulation analyzed in Part 4.1 is used here to explain how difficult this search is. Assume that today the Senate ranks automobile safety first, the House prefers high-performance cars, and the President is concerned with fuel economy. An HSP core with these preferences is illustrated in Figure 5. The core point $s q$ represents the current, stable regulatory standard. The standard will produce safe cars that are not very fuel efficient and not much fun to drive.

Assume next that this is an election year for the Congress but not the President and a number of Senators are facing difficult races. The automobile industry and the United Auto Workers make contributions to

The theory of statutory interpretation thus should resist the idea that political cohesiveness alone renders political outputs suspect; for on this view, that a proposal passes would be a sufficient ground for suspecting the proposal. 
these Senators and lobby them about excessive regulation. The lobbyists claim that consumers dislike current cars and that a less exclusive focus on safety will make everyone happier. After the election, the new Senate's preferences regarding regulation change to the point represented by $S^{\prime}$ : this Senate has come to value safety less and performance more. The new core is $H S^{\prime} P$. In consequence, the relevant statute is amended to require the new regulatory standard summarized by point $x$. Note that point $x$ represents an improvement for the President and the House, whose preferences did not change.

In the example, a new statute was passed that will reduce automobile safety. The jointly necessary and sufficient conditions for the statutory change to $x$ were that the Senate's preferences changed, the House's preferences remained the same, and the President's preferences remained the same. It is difficult to go further than this. Neither the House nor the President were lobbied in this story. Did the statute pass because key Senators were lobbied or because the President and House appropriately held unchanged beliefs?

A capture theory apparently should answer these questions. A Senator accused of selling out to business interests can claim with apparent plausibility that the new statute was passed "because" the President was powerful and preferred fuel efficient cars to safe ones at the margin and also "because" the House was more willing than it to sacrifice safety to handling quality. It is difficult convincingly to say that the statute passed "because" lobbyists captured the Senate if one cannot convincingly say that the Senate's preference change caused the new law.

One may attempt to avoid this problem by focusing less on changes in the preferences of legislators and more on how those changes were induced. Thus, in the example a change in the Senate's preferences was a necessary condition of a move to less safe regulation, and the preference change was induced by lobbying and campaign contributions. Focusing on how political change was produced is to treat cause functionally. A functional theory of causation attaches the label "the cause" to one of the necessary conditions of an event in order to bring about or to deter particular states of affairs. For an analogy, the economic theory of torts attributes "the cause" of an accident to the cheapest cost avoider in order to impose liability on the class of actors that can most efficiently reduce accident costs. Similarly, a capture theory could attribute "the cause" of 
passage of the new statute in the example here to lobbying of the Senate if (1) the lobbying induced some Senators to alter their preferences, (2) the preference change was a necessary condition of the statute's passage, and (3) deterring the lobbying of Senators regarding safety would produce more efficient safety regulation.

The last step is problematic: as far as is known, the correlation between lobbying and inefficient legislative outputs is much weaker than the correlation between, say, monopoly power and noncompetitive prices. Lobbyists sometimes provide legislators with useful information about the consequences of proposed laws. Lobbyists also sometimes serve the cause of efficiency, as when they oppose inefficient regulations that are meant to protect particular industries. Therefore, in the example here, if Congress should pursue efficiency, then a lobbying induced legal change would be "the cause" of that change only in circumstances when lobbying is likely to be a necessary (or predisposing) cause of inefficient safety laws generally. At present, criteria that would permit courts to identify these circumstances do not exist. A consequence of this gap is that capture claims cannot be evaluated with functional theories of causation.

Turn next to the second requirement for justifying judicial causation inquiries-implementing what the legislature would have enacted had no invidious causes been present. In the example here, if lobbying the Senate was an invidious cause of the new statute, then had that cause been absent, the status quo regulation-point $s q$-would have obtained. This result would not satisfy the second requirement, however, because $s q$ itself may have been the product of prior invidious political factors. To avoid this possibility, a court apparently must start from scratch and ask what the Congress would have done under ideal conditions.

This question is similar to the task that Michael Levine set for those claiming that capture had occurred, which was to compare actual political outcomes to the outcomes that a polity free from (political) transactions costs would have generated (Levine and Forrance, 1990). This way of putting the issue cannot avoid the causation difficulty. Initially, it is difficult to tell when a political practice is a transaction cost or a useful input. For example, if an interest group has low coalition costs, it can organize to influence votes independently of the merits or to tell an efficiency story to legislators. Both of these activities may require campaign contributions-to influence the vote itself or to get a busy legislator 
to hear the message. The ability to raise money efficiently, like lobbying in the model here, can produce suboptimal outcomes (then political cohesiveness is a cost) or optimal outcomes (then political cohesiveness is a gain). Knowing when low coalition costs are more likely than not to yield inefficiency requires more theory than now exists. Further, it is difficult to know what a polity free from transaction costs would have done..$^{51}$

Finally, a theory of causation sometimes used by historians attributes the "cause" of an unusual event to the least typical necessary cause of that event. Thus, it was the largest rainfall in ten years that caused flooding losses rather than the penchant of people to build in flood plains. This theory of causation cannot help with capture issues. In the example above, even if the new safety statute could be described as unusual, lobbying legislators is normal business.

Lobbying and campaign contributions commonly are necessary conditions for statutory change. Nothing said here should be taken to deny that these changes sometimes are for the worse. It is appropriate, therefore, for Congress to regulate the practices that are used to influence it, and Congress occasionally has done so. Thus, lobbyists must register, disclose their employers, and so forth. The state courts cannot regulate attempts to influence the national legislature, however. Rather, these courts need, but lack, a causation theory that would permit them to

51. The text discusses the political transaction costs that are usually mentioned in capture discussions, such as lobbying and giving politicians money. A different category of political transaction costs exists that can prevent democratic polities from implementing efficient policies. For example, politicians find it difficult to make credible long-term commitments to deals under which it is efficient to compensate the losers from an efficient policy. As a consequence, if the losers will not be fully paid off early, they may block the policy. A technical analysis of this and related problems is Besley and Coate (1998). A good nontechnical survey of the political transaction costs that make the implementation of efficient policies difficult is Dixit (1996). Political transaction costs such as these seem irrelevant to the capture issues discussed here. As an illustration, the difficulty politicians face in committing credibly to deals that would extend through time may lessen the likelihood that efficient safety regulations will be passed but does not imply that any inefficiencies will systematically benefit producers. 
know when they should use statutory interpretation to improve legislative products. ${ }^{52}$

To summarize, the weak form of the capture claim that partly sustains current law holds that when Congress enacts a bad law because of defects in the political process, the state courts should not defer fully to that law. This claim founders over two difficulties: courts cannot tell when bad political practices caused bad laws, and courts cannot know what laws would have been passed had the bad political practices been absent. ${ }^{53}$ Perhaps for these reasons, capture is not an issue in actual products liability cases. Rather, the state courts tacitly and the ALI explicitly have assumed that "capture" is ubiquitous-the strong form of the capture objection. Partly as a consequence, state law treats all federal regulations as presumptive floors. The strong form of the capture objection must fall with the weak form, however. To say that capture always exists, although it can never be identified, is too hard a position to defend. ${ }^{54}$

52. Interest groups apparently have a theory of causation because they give money to political actors. There is a question, however, whether money is given to influence elections or votes on statutes. If the former, then it is hard to say that a particular statute was caused by capture. The debate is summarized in Stratmann (1998) (arguing, with data from farm support votes, that when only a single cohesive interest group is present it tries to influence both elections and votes). An interest group's theory of causation also should not be the law's theory. One reason for this view is that an interest group may give money to a congressperson whose constituents support the desired legislation-price supports in a farm state-because such a legislator is less likely to renege on a promise to vote as the group desires. The contribution is meant to prevent the legislator from going against her constituent's (and the interest group's) preferences. A legislator who votes as her constituents want apparently is not captured by an interest group. More importantly, it may be enough for an interest group to make itself a necessary condition of statutory change. On the argument above, however, state courts must identify sufficient conditions.

53. The discussion in text used the efficiency norm, but the same results would obtain if the word equity was substituted for efficiency in every sentence. The general problem is the inability to link political practices causally to political outcomes.

54. Levine, supra note 45 , believes, with reference to agencies, that "It is only meaningful to talk about 'capture' if the regulator decides in a self-regarding way to use the shelter from political risk created by imperfect monitoring ... to adopt a policy favored by a beneficiary (typically an organized subgroup of the polity) from which she expects to benefit personally (in political support, future employment, or direct bribery)." Levine would also apply this definition to Congress. Since legislators commonly do things for political support, focusing on this criterion would recreate the difficulties noted above. Limiting the definition of capture to cases of overt or thinly concealed pursuit of personal, nonpolitical gain seems sound, however. 


\section{Conclusion}

Products liability law contains a doctrine of partial substantive preemption: the courts treat noncompliance with a federal safety statute or regulation as negligence per se, and treat compliance only as evidence that a jury can consider in deciding whether a firm made a defective product. Congress can decide what weight in tort suits federal regulations should have, but the state courts need a rule of interpretation when a federal safety statute is unclear (as commonly happens). The current rule assumes that Congress intends always to enact regulatory floors. This article has argued for a different rule of interpretation, which would require courts to take statutes to enact full substantive preemption unless reasons existed that could have persuaded a public regarding Congress to supplement federal regulation with state tort law. This interpretative rule attributes to Congress, in the general case, the intention to require firms that violate regulations to be held liable but to exculpate firms that comply. The proposed rule follows from two constructions of legislative intent: Congress would prefer the typical safety regulation to be nationally uniform, and Congress would prefer state courts to read federal laws in ways that maximize the ability of the national government to correct interpretative mistakes. For reasons given above, it is easier for Congress to correct state court interpretations that suppose Congress to want too much safety than interpretations that suppose it to want too little. Defenses of the current rule of interpretation, that Congress and its agencies tend to be captured by private interests or that the state courts can usefully supplement efficiency seeking federal regulatory schemes, are unpersuasive. Capture theory is insufficiently advanced to permit courts to make reliable capture determinations. And courts and juries seldom could improve federal safety regulations.

Whether these arguments fully persuade, it is clear that the state courts created, and the ALI recently endorsed, the current regulatory compliance defense with little serious consideration of the statutory interpretation, federalism, and institutional competence issues discussed here. ${ }^{55} \mathrm{~A}$ well-

55. The ALI's failure to focus on these issues was not accidental. These issues are relevant to consideration of how the law could be improved. Throughout the Products Liability restatement process and after, plaintiffs' lawyers accused the ALI of engaging in "law reform." One of the two reporters for the Products Liability Restatement, 
grounded justification of the defense would take the broader issues into account. Doing this suggests a final thought. An important part of state tort law may lack political legitimacy, in the sense that the law ignores what seems the likely Congressional will.

\section{Appendix}

\section{Preemption Provisions of Selected Federal Statutes}

Federal Insecticide, Fungicide, and Rodenticide Act. 7 U.S.C.A. $§ 136 \mathrm{v}$ (1997). In general, a state may regulate the sale and use of pesticides or devices covered by the act, although the state may not permit any sale or use prohibited by the Act. Nonetheless, the state may not impose any labeling or packaging requirements different from those required by the Act.

The section on the Act's interaction with state law also includes a process under which states may introduce registrations for additional uses of federally registered pesticides "to meet special local needs."

Flammable Fabrics Act. 15 U.S.C. $§ 1203$ (1994). States or political subdivisions of states may not impose or continue to enforce flammability and related requirements upon the fabrics and other materials covered by the Act, unless those regulations are identical to the federal regulation.

A state or political subdivision of a state may apply for an exemption to this rule, if (1) compliance with the proposed regulation does not result in a violation of another standard in the Act, (2) the regulation provides a "significantly higher degree of protection" from the risk of fire (the target of the federal regulation), and (3) it does not unduly burden interstate commerce.

Note on history: The specific preemption language from which the above summary was taken was added in a 1976 amendment.

James Henderson, denied this charge: "Henderson also shrugged off the plaintiffs' attorneys' charges, saying tort reform was neither the goal of the project, nor the drafters' intent." Rather, Henderson described the the Restatement "as a fair and balanced recitation of current law and the rationale behind it" (BNA Product Liability Daily, May 23, 1997). That the ALI would take five years to tell the profession what anyone who read the cases already knew was predictable: the ALI only improves areas of the law that hardly matter (Schwartz and Scott, 1995). 
Federal Hazardous Substances Act. 15 U.S.C. $§ 1261$, notes (1994). The preemption provisions, here placed in the notes to the Act, are identical to those for the Flammable Fabrics Act above.

Federal Cigarette Labeling and Advertising Act. 15 U.S.C. $§ 1334(\mathrm{~b})$ (1994). No requirement or prohibition based on smoking and health shall be imposed under State law with respect to the advertising or promotion of any cigarettes, the packaging of which are labeled in conformity with the provisions of this chapter.

Poison Prevention Packaging Act of 1970. 15 U.S.C. § 1476 (1994). The preemption provisions for this Act are identical in structure to those for the Flammable Fabrics Act above.

Consumer Product Safety Act. 15 U.S.C. § 2075(a) (1994) Whenever a consumer product safety standard under this chapter is in effect and applies to a risk of injury, no state may establish or continue in effect any provision which prescribes in relation to performance, composition, contents, design, finish, construction, packaging, or labeling which are designed to deal with the same risk of injury, unless the requirements are identical to the requirements of the Federal standard. 15 U.S.C. §2075(b) (1994)

Notwithstanding $\$ 2075(a)$, a state may create regulations that impose a higher standard of protection.

The state or political subdivision of the state must apply to the Commission for exemption from (a). Exemption will be granted if the following conditions are met: (1) The regulation provides significantly higher degree of protection from risk of injury. (2) The regulation does not unduly burden interstate commerce.

Note on history: By amendment in 1976, language referring to a significantly higher level of performance was replaced by language referring to requirements that would "provide a significantly higher degree of protection."

Magnuson-Moss Warranty Federal Trade Commission Improvement Act. 15 U.S.C. $\$ 2311$ (1994). This section contains an explicit statement that this chapter shall not invalidate any consumer right or remedy under state 
law or any other federal law. In addition, the chapter is not to affect the liability of, or impose liability on, any person for personal injury, or supersede any provision of state law concerning consequential damages.

State law concerning labeling or disclosure with respect to written warranties, and which is under the scope of the Act, shall not apply to written warranties unless the state law is identical to the federal law.

States may apply to the Commission for approval of requirements if these requirements provide greater protection for the consumer and does not unduly burden interstate commerce.

Toxic Substances Control Act. 15 U.S.C. §2617 (1994). The preemption structure for this act is substantially similar to that included in the Flammable Fabrics Act above. One difference is that the Administrator is given more authority within the Act to establish rules governing the testing of toxic substances.

Federal Food, Drug, and Cosmetic Act. National uniform nutrition labeling. 21 U.S.C. \$343-1 (1994). Generally bars states from imposing labeling requirements on food that is interstate commerce. [An exception is made, however, for maple syrup.]

A state or a political subdivision of a state may apply for an exemption from the bar on imposing labeling requirements, if (1) it would not cause any food to be in violation of any applicable federal requirement, (2) it would not unduly burden interstate commerce, and (3) it is designed to address a particular need not met by the federal requirements.

Interstate sale of colored oleomargarine. 21 U.S.C. $\$ 347 b$ (1994). Nothing in this Act shall be construed as authorizing the possession, sale, or serving of colored oleomargarine or colored margarine in any State or Territory in contravention of the laws of such State or Territory.

Medical devices. 21 U.S.C. $\$ 360 \mathrm{k}$ (1994). No state or political subdivision of a state may establish any requirement different from the federal requirements for devices, unless (1) the requirement is more stringent than the federal requirement, and (2) the requirement is "required by compelling local conditions," and (3) compliance with the requirement would not cause the device to be in violation of another applicable federal requirement under this chapter. 
Radiation Control for Health and Safety Act of 1968. 21 U.S.C. \$360pp (1994). Explicit statement that conformity with regulations will not relieve any person from liability at common law or statutory law.

21 U.S.C. §360ss (1994). States and political subdivisions of states may not establish any requirement that is not identical to the federal standard if that requirement is applicable to an aspect of performance of an electronic product covered by the Act. States and political subdivisions of states may establish requirements with respect to emission of radiation of products for their own use, provided that these requirements are more restrictive than the otherwise applicable federal standard.

National uniformity for nonprescription drugs. 21 U.S.C.A. §379r (West Supp. 1998). In reference to most drugs covered by the section, states or political subdivisions of states are prohibited from establishing requirements that differ from those in the Act, or in the Poison Prevention Packaging Act of 1970 (15 U.S.C. 1471 et seq.), or in the Fair Packaging and Labeling Act (15 U.S.C. 1451 et seq.).

States may apply for an exemption from this prohibition if the proposed regulation (1) "protects an important public interest that would otherwise be unprotected, including the health and safety of the children," (2) would not cause any drug to be in violation of any applicable requirement under federal law, and (3) would not unduly burden interstate commerce.

In addition, this section does not apply to requirements adopted by state initiative or referendum enacted prior to September 1, 1997.

In addition, §379r includes a section entitled "No effect on product liability law." According to this section, the larger section is not to "modify or otherwise affect any action or the liability of any person under the product liability of any State."

Note on history: the provisions outlined above were introduced in an amendment effective November 21, 1997.

Preemption for labeling or packaging of cosmetics. 21 U.S.C.A. §379s (West Supp. 1998). This section is substantially similar in structure to that of $\S 379 \mathrm{r}$ above.

Poultry and poultry products inspection. 21 U.S.C. $\$ 678$ (1994). This section prohibits states from establishing new requirements with respect to premises, facilities, and operations of establishments governed by the 
Act's inspection requirements, except that states may impose certain record keeping requirements.

Occupational Health and Safety Act. 29 U.S.C. $\$ 667$ (1994). This section of the Act permits state agencies and courts to assert jurisdiction concerning safety or health issues not addressed by OSHA.

The section also includes procedures for states to apply to assume responsibility for developing and enforcing standards relating to issues regulated by OSHA. The Secretary may approve such petitions if the standards to be enforced by the state are (1) at least as effective as OSHA's standards, (2) are "required by compelling local conditions," and (3) do not unduly burden interstate commerce.

Other conditions, such as adequate funding and supervision, rights of inspection, and reporting requirements, are also to be considered by the Secretary.

Oil Pollution Act of 1990. 33 U.S.C. $\$ 2718$ (1994). The Act shall not prevent states from imposing additional liability or requirements with respect to the discharge of oil or other pollution in the state, or any removal activities in connection with such discharge.

In addition, the Act is not to affect the liabilities of any person under the Waste Disposal Act or state law, including common law.

Comprehensive Environmental Response, Compensation, and Liability Act of 1980.42 U.S.C. $\$ 9614$ (1994). The first subsection of this section declares that states are not preempted from imposing additional liability or requirements with respect to the release of hazardous substances.

If certain compliance with the Act's regulations is performed, then the service station dealer may not be held liable under certain sections of the act, provided that the dealer complied with regulations. However, the section states that this does not affect the obligations or liability of any person under any other provision of state or federal law, including common law. In the area of financial responsibility, however, the federal requirements for the operators of vessels or facilities must be accepted by any state in lieu of that state's financial responsibility requirements, at least insofar as those regulations relate to liability for the release of hazardous substances. 
National Childhood Vaccine Injury Act of 1986. 42 U.S.C. \$300aa-22 (1997). State law is to apply to civil actions brought for damages in vaccine-related injury or death unless the suit concerns a situation in which proper warnings were given and the death or injury resulted from an unavoidable side effect.

The warnings will be considered proper for this inquiry if the manufacturer complied with all of the federal warning requirements, unless the plaintiff shows (1) that the manufacturer engaged in some kind of fraud or other intentional misconduct during the vaccine's approval phase, or (2) the plaintiff shows by clear and convincing evidence that the manufacturer failed to exercise due care notwithstanding the compliance with the federal requirements.

No state may bar an individual from bringing a civil action against a manufacturer for vaccine-related injury unless the action is barred by this part of the Act.

Federal Boat Safety Act. 43 U.S.C.A. $§ 4306$ (West Supp. 1998). Unless the Secretary issues an exemption, no state or political subdivision of a state may establish any requirement that is not identical to the applicable federal requirement, unless (barring the disapproval of the Secretary), the requirement relates to the carrying or use of marine safety articles "to meet uniquely hazardous conditions or circumstances within the State."

Communications Act. 47 U.S.C. $\$ 414$ (1994). Nothing in the chapter is to abridge existing remedies under common law or by statute, but is to be in addition to such remedies.

National Traffic and Motor Vehicle Safety Act. 49 U.S.C.A. $\$ 30103$ (1997). States are allowed to establish requirements if they mandate a "higher performance standard."

The Act expressly states that compliance with its standards does not exempt a person from liability at common law.

Federal Aviation Act. 49 U.S.C.A. $\$ 41713$ (1997). This section prohibits states, political subdivisions of states, or "political authority of at least 2 States" from enforcing law, regulations, or provisions relating to price, route or service. Exceptions are for certain transportation within Alaska, and for the proprietary rights of holders of certificates issued by the Department of Transportation. 


\section{References}

American Law Institute. 1997. Restatement of the Law, Products Liability $§ 4$. Philadelphia: American Law Institute.

American Law Institute Reporters' Study. 1991. Enterprise Responsibility for Personal Injury, Volume II, p. 100.

Ausness, Richard C. 1996. "The Case for a 'Strong' Regulatory Compliance Defense," 55 Maryland Law Review 1210-67.

Austen-Smith, David, and Jeffrey S. Banks. 1997. "Social Choice Theory, Game Theory, and Positive Political Theory," Discussion Paper No. 1196, Center for Mathematical Studies in Economics and Management Science, Northwestern University.

Besley, Timothy, and Stephen Coate. 1998. "Sources of Inefficiency in a Representative Democracy: A Dynamic Analysis," 88 American Economic Review 139-56.

Binder, Sarah A., and Steven S. Smith. 1998. "Political Goals and Procedural Choice in the Senate," 60 Journal of Politics 398-416.

BNA Product Liability Daily, May 23, 1997.

Campbell, Jack W., IV. 1998. "Regulatory Preemption in the Garcia/Chevron Era," 59 University of Pittsburgh Law Review 805-850.

Chapman, Bruce, and Michael J. Trebilcock. 1992. "Making Hard Social Choices: Lessons from the Auto Accident Debate," 44 Rutgers Law Review 797-869.

Craswell, Richard, and John E. Calfee. 1986. "Deterrence and Uncertain Legal Standards," 2 Journal of Law, Economics \& Organization 279-304.

Cupp, Richard L., Jr. 1997. "The 'Uncomplicated' Law of Products Liability: Reflections of a Professor Turned Juror," 91 Northwestern Law Review 1082-1107.

Dixit, Avinash K. 1996. The Making of Economic Policy: A Transaction-Cost Politics Perspective. Munich Lectures in Economics. Cambridge, MA: MIT Press.

Dworkin, Ronald. 1986. Law's Empire. Cambridge, MA: Belknap Press.

Elhauge, Einer R. 1991. "Does Interest Group Theory Justify More Intrusive Judicial Review?" 101 Yale Law Journal 31-110.

Epstein, David, and Sharyn O'Halloran. 1995. "A Theory of Strategic Oversight: Congress, Lobbyists and the Bureaucracy," 11 Journal of Law, Economics \& Organization 227-55.

Eskridge, William N., Jr. 1989. "Public Values in Statutory Interpretation," 137 University of Pennsylvania Law Review 1007-1104.

1994. Dynamic Statutory Interpretation. Cambridge, MA: Harvard University Press.

Farber, Daniel A., and Philip P. Frickey. 1991. Law and Public Choice: A Critical Introduction. Chicago: University of Chicago Press. 
Ferejohn, John, and Barry R. Weingast. 1992. "Limitation of Statutes: Strategic Statutory Interpretation," 80 Georgetown Law Journal 565-82.

Frailberg, Jeremy D., and Michael J. Trebilcock. 1998. "Risk Regulation: Technocratic and Democratic Tools for Regulatory Reform," 43 McGill Law Journal 835-87.

Gehrlein, William V. 1998. "The Probability of a Condorcet Winner with a Small Number of Voters," 59 Economics Letters 317-21.

Gillette, Clayton P., and James E. Krier. 1990. "Risk, Courts and Agencies," 138 University of Pennsylvania Law Review 1027-1109.

Green, Michael D. 1997. "Cippilone Revisited: A Not So Little Secret About the Scope of Cigarette Preemption," 82 Iowa Law Review 1257-67.

Hammond, Thomas H., and Jack H. Knott. 1996. "Who Controls the Bureaucracy: Presidential Power, Congressional Dominance, Legal Constraints, and Bureaucratic Autonomy in a Model of Multi-Institutional Policy-Making," 12 Journal of Law, Economics, \& Organization 119-68.

Kolstad, Charles D., Thomas S. Ulen, and Gary V. Johnson. 1990. "Ex Post Liability for Harm vs. Ex Ante Safety Regulation: Substitutes or Complements?" 80 American Economic Review 888-901.

Kreimer, Seth F. 1984. "Allocational Sanctions: The Problem of Negative Rights in a Positive State," 132 University of Pennsylvania Law Review 1293-1397.

Levine, Michael E. 1998. "Regulatory Capture," 3 New Palgrave Dictionary of Economics and Law 267-71.

Levine, Michael E., and Jennifer L. Forrance. 1990. "Regulatory Capture, Public Interest, and the Public Agenda: Toward a Synthesis," 6 Journal of Law, Economics, \& Organization 167-98 (Special Issue).

Luban, David. 1998. "A Flawed Case Against Punitive Damages," 87 Georgetown Law Journal 359-80.

Lupia, Arthur, and Mathew D. McCubbins. 1994. "Learning from Oversight: Fire Alarms and Police Patrols Reconstructed," 10 Journal of Law Economics, \& Organization 96-125.

Macey, Jonathan R. 1986. "Promoting Public Regarding Legislation Through Statutory Interpretation: An Interest Group Model," 86 Columbia Law Review 223-68.

Mashaw, Jerry L. 1997. Greed, Chaos and Governance: Using Public Choice to Improve Public Law. New Haven: Yale University Press.

McCubbins, Mathew, Roger G. Noll, and Barry Weingast. 1987. "Administrative Procedures as Instruments of Political Control," 3 Journal of Law, Economics \& Organization 243-78.

- 1989. "Structure and Process, Politics and Policy: Administrative Arrangements and the Political Control of Agencies," 75 Virginia Law Review $431-82$. 
McCubbins, Mathew, and Thomas Schwartz. 1984. "Congressional Oversight Overlooked: Police Patrols versus Fire Alarms," 28 American Journal of Political Science 165-79.

Miller, Gary. 1997. "The Impact of Economics on Contemporary Political Science," 35 Journal of Economic Literature 1173-1204.

Mueller, Dennis C. 1989. Public Choice II. New York: Cambridge University Press.

Olson, Mary K. 1999. "Agency Rulemaking, Political Influence, Regulation, and Industry Compliance," 15 Journal of Law, Economics, \& Organization 573-601.

Ordeshook, Peter C. 1986. Game Theory and Political Theory: An Introduction. New York: Cambridge University Press.

Pakes, Ariel, and Paul McGuire. 1994. "Computing Markov-Perfect Nash Equilibria: Numerical Implications of a Dynamic Differentiated Product Model," 25 Rand Journal of Economics 555-89.

— 1996. "Stochastic Algorithms for Dynamic Models: Markov Perfect Equilibrium and the 'Curse' of Dimensionality," mimeo, Yale University Department of Economics.

Rabin, Robert L. 1997. "Federalism and the Tort System," 50 Rutgers Law Review 1-31.

Raz, Joseph. 1994. Ethics in the Public Domain: Essays in the Morality of Law. New York: Oxford University Press.

Riker, William H. 1982. Liberalism Against Populism: A Confrontation Between the Theory of Democracy and the Theory of Social Choice. San Francisco: W.H. Freeman.

Rubin, Paul H., John E. Calfee, and Mark F. Grady. 1997. "BMW vs. Gore: Mitigating the Punitive Economics of Punitive Damages," 5 Supreme Court Economic Review 179-216.

Schwartz, Alan, and Robert E. Scott. 1995. "The Political Economy of Private Legislatures," 143 University of Pennsylvania Law Review 595-654.

Shepsle, Kenneth A., and Barry R. Weingast. 1984. "Uncovered Sets and Sophisticated Voting Outcomes with Implications for Agenda Institutions," 28 American Journal of Political Science 49-74.

Sherman, Paul. 1992. "Use of Federal Statutes in State Negligence Per Se Actions," 13 Whittier Law Review 831-908.

Spiller, Pablo T., and Emerson H. Tiller. 1997. "Decision Costs and the Strategic Design of Administrative Process and Judicial Review," 26 Journal of Legal Studies 347-70.

Spitzer, Matthew L. 1988. "Antitrust Federalism and Rational Choice Political Economy: A Critique of Capture Theory," 61 Southern California Law Review 1293-1326.

Stratmann, Thomas. 1998. "The Market for Congressional Votes: Is Timing of Contributions Everything?" 41 Journal of Law \& Economics 85-113. 
Sunstein, Cass R. 1990. After the Rights Revolution: Reconceiving the Regulatory State. Cambridge, MA: Harvard University Press.

Tabarrok, Alexander, and Eric Helland. 1999. "Court Politics: The Political Economy of Tort Awards," 42 Journal of Law \& Economics 157-88.

Tushnet, Mark. 1988. Red, White, and Blue: A Critical Analysis of Constitutional Law. Cambridge, MA: Harvard University Press.

Van Deeman, Adrian. 1999. "The Probability of the Paradox of Voting for Weak Preference Orderings," 16 Social Choice \& Welfare 171-82.

Varian, Hal R. 1992. Microeconomic Analysis (3d ed.) New York: W.W. Norton.

Viscusi, W. Kip, Steven R. Rowland, Howard L. Dorfman, and Charles J. Walsh. 1994. "Deterring Inefficient Pharmaceutical Litigation: An Economic Rationale for the FDA Regulatory Compliance Defense," 24 Seton Hall Law Review 1437-80.

Warren, Ashley W. 1997. "Compliance With Governmental Regulatory Standards: Is It Enough to Immunize a Defendant from Liability?" 49 Baylor Law Review 763-816.

\section{Case References}

Lewis v. Brunswick Corporation, 107 F.3d $1494\left(11^{\text {th }}\right.$ Cir. 1997), cert. dismissed, 66 U.S.L.W. 3753 (1998)

Medtronic Inc. v. Lohr, 518 U.S. 470 (1996)

Myrick v. Frehauf Corp, 115 S. Ct. 1483 (1995)

Taylor v. General Motors Corp., 873 F.2d 816 (11 ${ }^{\text {th }}$ Cir. 1989) 